\title{
Cassatie in strafzaken (Nederlands recht)
}

\author{
Willem van Schendel*
}

\section{Inleiding en vraagstelling}

'Eindelijk neem ik gaarne aan dat de arbeid, die in dit opzicht van ons hoogste rechtscollege wordt geuraagd, verre van aangenaam en benijdenswaard is. ${ }^{\text {I }}$

I.I Rechtsstatelijke rechtspraak wordt gekenmerkt door procedurele zorgvuldigheid en inhoudelijke kwaliteit. De cassatie als instituut is gericht op de bewaking van de kwaliteit van het recht. ${ }^{2}$ Kan de Hoge Raad zijn taak tot het waarborgen van de kwaliteit van de rechtspraak in strafzaken op adequate wijze (blijven) vervullen? Ziedaar de eenvoudige vraagstelling van dit preadvies. Mijn antwoord zal teleurstellend weinig oorspronkelijke gedachten bevatten. Dat is niet verwonderlijk, omdat de afgelopen jaren, ingebed in fundamentele beschouwingen over de doeleinden van het proces, de rol van de procesdeelnemers en het stelsel van rechtsmiddelen, reeds in verheugend ruime mate aandacht is besteed aan het rechtsmiddel cassatie, aan de plaats en taak van de cassatierechter en de noodzaak of wenselijkheid van wezenlijke veranderingen. Niet alleen in strafvorderlijk verband, ${ }^{3}$ maar ook in het kader van het burgerlijk procesrecht. ${ }^{4}$

Elke bijdrage aan het debat - ook in het buitenland - begint met de verzuchting dat de werklast te groot dreigt te worden en dat de cassatierechter zijn taak uiteindelijk alleen behoorlijk kan blijven vervullen als ingrijpende maatregelen worden getroffen. Als aanleiding tot onderzoek is het begrijpelijk, maar toch heb ik dat altijd een wat ongemakkelijk vertrekpunt gevonden. Niet omdat ik zou willen beweren dat ik het in de Strafkamer niet erg druk heb, maar omdat ik meen dat het argument van de werkbelasting in beginsel van interne, financiële, administratieve en organisatorische aard is en niet geschikt om overtuigend te funderen dat, waarom en in hoeverre de taak en werkwijze van de cassatierechtspraak dient te worden gewijzigd. Op praktische bezwaren passen immers antwoorden in de sfeer van stroomlijning van werkwijzen, uitbreiding van de personele bezetting of betere computerprogramma's. Natuurlijk is de toegang tot de rechter een schaars goed 5 en zal er dus

^. Willem van Schendel is raadsheer in de Hoge Raad.

I. Jhr. Mr. Rh. Feith, Het Bewijs in strafzaken, Praeadvies, Handelingen der Nederlandsche JuristenVereeniging I9IO, p. 3I-32. Zijn aanname is mij later onjuist gebleken.

2. Zie in het algemeen: De sociale rechtsstaat voorbij. Twee ontwerpen voor het huis van de rechtsstaat. Rapport van de Wetenschappelijke Raad voor het Regeringsbeleid (WRR) 2002, p. 68 e.v.

3. Zie: E.F. Stamhuis, De cassatierechter in strafzaken, in: M.S. Groenhuijsen en G. Knigge (red.), Afronding en Verantwoording. Eindrapport onderzoeksproject Strafvordering 200I, Kluwer Deventer 2004, p. 42I e.v. (hierna: Stamhuis, a.w.).

4. Zie: W.D.H. Asser e.a. Uitgebalanceerd. Eindrapport Fundamentele herbezinning Nederlands burgerlijk procesrecht, Den Haag 2006, p. I5 I e.v.

5. Vergelijk: D. Schaffmeister, De rol van de Hoge Raad en de ontwikkeling van het cassatierecht in strafzaken, in: De plaats van de Hoge Raad in het huidige staatsbestel, Zwolle I988, p. II6 e.v. 
een zo evenwichtig mogelijke keuze gemaakt moeten worden tussen wat de Hoge Raad behoort te doen en wat hij aankan. Maar een maatstaf voor de beantwoording van de rechtspolitieke vraag naar de essentie van de functie van de cassatierechtspraak en de daaruit voortvloeiende taken en werkwijzen is natuurlijk niet te vinden in de constatering dat de bestaande praktijk een te zware druk legt op de Hoge Raad.

Aan de keuze van het vertrekpunt van de te grote werklast voor beschouwingen over cassatierechtspraak zal voor een belangrijk deel debet zijn dat in de strafvorderlijke wereld een aanzienlijke mate van consensus bestaat dat wezenlijke veranderingen in de functie van de cassatie en de taak van de cassatierechter niet gewenst zijn. ${ }^{6}$ Daarvan uitgaande en van de veronderstelling dat de grenzen van de werkdruk op niet onafzienbare termijn kunnen zijn bereikt, komt het dus erop aan te inventariseren welke de huidige taken en ingesleten werkwijzen zijn, na te gaan hoe noodzakelijk deze zijn met het oog op het doel waarvoor zij worden gehanteerd en praktische oplossingen te bedenken voor de geconstateerde bezwaren. Ik wil hier maar aangestipt hebben dat de primaire vraag steeds moet zijn welke taak de hoogste rechter dient te vervullen, en dat de vraag naar een goede organisatie en dus van beheersing van de werklast daarvan een afgeleide behoort te zijn. Dat constaterende, kies ook ik tot uitgangspunt mij te beperken tot de in grote trekken te handhaven bestaande inrichting van de cassatierechtspraak. Dat brengt mee dat ik geen aandacht zal besteden aan radicalere oplossingen voor het probleem van de werkbelasting, te weten verder gaande uitsluiting van cassatie of de introductie van (enige vorm van) een verlofstelsel, waarbij wezenlijk aan de toegang tot de cassatierechter wordt gesleuteld.

I.2 Ik beperk mij in het onderstaande tot cassatie in gewone strafzaken (dagvaardingszaken) als de meest voorkomende. Afwijkende regels in zaken afkomstig van de Nederlandse Antillen en Aruba, in verband met beschikkingen e.d. komen niet aan bod. Bijzondere procedures als de herziening (revisie) en die met betrekking tot rechtshulp- of uitleveringsverzoeken evenmin.

\section{Een korte schets van procedure en werkwijze}

2.I De strafkamer van de Hoge Raad telt tien leden, verdeeld over twee kamers. Acht leden treden op als rapporteur, ieder bijgestaan door één jonge jurist, medewerker van het wetenschappelijk bureau van de Hoge Raad. ${ }^{7}$ De beide vice-presidenten treden als voorzitter van een kamer op, ieder in globaal de helft van het aantal zaken. ${ }^{8}$ In beginsel wordt elke zaak aangebracht bij een formatie van drie raadsheren, die de zaak behan-

6. Zie ook: Stamhuis, a.w., p. 47I e.v.

7. Daarover: A.J.A. van Dorst, Het wetenschappelijk bureau, in: De Hoge Raad der Nederlanden I838-I988. Een portret, p. 3i9 e.v. De medewerkers zijn gemiddeld zes jaar werkzaam bij het wetenschappelijk bureau. Het is gebruikelijk dat zij na een aantal jaren wisselen van het Parket naar de Raad of omgekeerd.

8. In totaal gaat het in 2006 om 3599 ingekomen zaken (waarvan 33I2 dagvaardingszaken) en 3137 gedane uitspraken. Ter vergelijking: in 2003 bedroegen deze aantallen 3028 (waarvan 2828 dagvaardingszaken), resp. 3003. Zie voor verder cijfermateriaal: Hoge Raad der Nederlanden Verslag 2005 en 2006, p. I74 e.v. 
delt en beslist. Indien naar het oordeel van een van de leden van de kleine kamer behandeling en beslissing door vijf raadsheren gewenst is, wordt de zaak naar een uit vijf raadsheren bestaande kamer verwezen. Bij de beraadslagingen over deze 'vijfzaken' zijn alle tien leden van de strafkamer aanwezig, dus ook zij die de beslissing niet mede ondertekenen. Afdoening in drie-formatie bergt het gevaar in zich van tegenstrijdige uitspraken met die van de andere kleine kamers. Mede met het oog op de vereiste coördinatie nemen alle leden kennis van de concept-beslissingen in alle zaken, ook die zaken die in drie-formatie zullen worden afgedaan.

De Procureur-Generaal bij de Hoge Raad en de vier Advocaten-Generaal, ieder ondersteund door gemiddeld drie leden van het wetenschappelijk bureau, nemen conclusies in alle binnengekomen zaken waarin middelen zijn ingediend. De Procureur-Generaal en zijn Parket maken geen deel uit van het openbaar ministerie zoals dat op arrondissements- en ressortsniveau optreedt. ${ }^{9}$ Zijn positie is afzonderlijk geregeld in Hoofdstuk 3 van de Wet op de rechterlijke organisatie (art. III-I23 RO).

$\mathrm{Na}$ het nemen van de conclusie wordt door de griffie van de Hoge Raad de zaak aan een rapporteur toebedeeld. Dit geschiedt, zonder inhoudelijke toetsing, op administratief niveau. ${ }^{\text {IO }}$

2.2 De Hoge Raad neemt kennis van het beroep in cassatie ${ }^{\mathrm{II}}$ tegen handelingen, arresten, vonnissen en beschikkingen van de gerechtshoven en rechtbanken, ingesteld door hetzij een partij, hetzij in het belang der wet door de Procureur-Generaal. ${ }^{12}$ Geen cassatie kan worden ingesteld indien voor de betrokkene een ander gewoon rechtsmiddel openstaat of heeft opengestaan. ${ }^{13}$ Anders dan in civiele zaken $^{\mathrm{I} 4}$ is het niet mogelijk om zgn. sprongcassatie in te stellen tegen een vonnis in eerste aanleg. ${ }^{\mathrm{I}}$ In art. 427 van het Wetboek van Strafvordering (Sv) wordt geregeld

9. Zie over de positie van de Procureur-Generaal en het Parket: G.J.M. Corstens, Het Nederlands strafprocesrecht, vijfde druk, p. IIg e.v.

Io. Zaakstoewijzing is in Nederland een interne aangelegenheid van de gerechten, waaromtrent de criteria niet openbaar zijn. Daarover: Ph. M. Langbroek en M. Fabri, Toedeling van zaken binnen het gerecht: regels en praktijk in vijf Europese landen en in Nederland, Rechtstreeks (uitgave Raad voor de Rechtspraak) 2006, nr. 2, p. 3 e.v; N. Huls en D. Vermeer, Vertrouwen in en zelfvertrouwen bij de rechterlijke macht, Rapport in opdracht van het Ministerie van Justitie, I december 2006, p. 33 e.v.

II. Zie over cassatie in het algemeen: A.L. Melai \& M.S. Groenhuysen e.a., Het wetboek van strafvordering, Kluwer Deventer (losbladig) aantekeningen ad art. 427 e.v. en A.J.A. van Dorst, Cassatie in strafzaken, Studiepockets Strafrecht 9, vijfde druk, W.E.J. Tjeenk Willink Deventer 2004 (hierna aangehaald als: Van Dorst, Cassatie).

I2. Art. 78, eerste lid, Wet op de Rechterlijke Organisatie (RO). Enige uitzonderingen staan in de leden twee en drie van deze bepaling. Geen cassatie staat dus open tegen handelingen of beslissingen van de politie, het openbaar ministerie, de griffier e.d. Zie: Van Dorst, Cassatie, p. I7.

I3. Art. 78, vijfde lid, RO. In verband daarmee zijn de regels van hoger beroep (art. 404 Sv) en verzet (art. 399 Sv) van belang. Zie: Van Dorst, Cassatie, p. 2I-22.

I4. Art. 398 Wetboek van burgerlijke rechtsvordering.

I5. HR 27 mei 1997 DD 97.265 acht dit met het gesloten stelsel van rechtsmiddelen niet verenigbaar en de rechtsvormende taak van de rechter te buiten gaan. De Hoge Raad converteert het cassatieberoep tegen het vonnis van de Politierechter (die ten onrechte had medegedeeld dat cassatieberoep open stond) in hoger beroep. In de schriftuur had de verdachte aangegeven dat hij zich niet in zijn belangen geschaad achtte door het missen van een tweede feitelijke instantie. Ik zou mij inmiddels een andere beslissing kunnen voorstellen. Waarom zouden partijen ook in strafzaken niet in voorkomende gevallen een instantie mogen overslaan, in het bijzonder als een typisch rechtspunt voorligt? Zie over sprongcassatie in het burgerlijk procesrecht: Asser Procesrecht/ Veegens-Korthals Altes-Groen (2005) nr. 40. 
wie tegen welke beslissingen beroep in cassatie kan instellen. Tot degenen die cassatie kunnen instellen behoren vanzelfsprekend de verdachte en het openbaar ministerie bij het gerecht dat de uitspraak heeft gedaan. ${ }^{16}$ De benadeelde partij die zich in het strafgeding heeft gevoegd, speelt in cassatie een beperkte rol. ${ }^{17}$ Het komt erop neer dat de benadeelde partij alleen in cassatie kan klagen als het gerechtshof op haar vordering een beslissing heeft gegeven en hetzij de verdachte hetzij het openbaar ministerie cassatie heeft ingesteld, en dan nog alleen over een rechtspunt hetwelk uitsluitend haar vordering betreft (art. 437, derde lid, Sv). De wet staat niet toe dat de benadeelde partij de zaak zelfstandig aan de Strafkamer van de Hoge Raad voorlegt en de Hoge Raad heeft geen ruimte gezien daarin verandering te brengen. ${ }^{\text {I8 }}$

Beroep in cassatie kan worden ingesteld tegen einduitspraken ${ }^{19}$ van het gerechtshof, met een beperking wat betreft veroordelingen ter zake van overtredingen. ${ }^{20}$ Tegen uitspraken die geen einduitspraken zijn (tussenuitspraken) - beslissingen in de loop of na afloop van het onderzoek ter terechtzitting waarmee geen einde aan de zaak wordt gemaakt - is beroep in cassatie slechts gelijktijdig met dat tegen de einduitspraak toegelaten (art. $428 \mathrm{~Sv}$ ). ${ }^{2 \mathrm{I}}$ Ook tegen vrijspraken is beroep in cassatie toegelaten. Het voordien geldende verbod is per I januari 2003 door schrapping van art. $430 \mathrm{~Sv}$ vervallen. De wetgever achtte het vooral belangrijk dat de Hoge Raad aldus nadrukkelijker een rol zou kunnen spelen op het terrein van het onrechtmatig verkregen bewijs, doordat vrijspraken die stoelen op een verkeerde toepassing van regels van bewijsrecht aan het oordeel van de Hoge Raad zouden kunnen worden onderworpen. ${ }^{22}$ In de praktijk lijkt het veelal te gaan om door het openbaar ministe-

I6. Tegenwoordig beschikt het openbaar ministerie over een zgn. cassatiedesk, ondergebracht bij het Parket-Generaal ter bevordering van de kwaliteit van de door het OM bij de gerechten in te stellen cassaties door bundeling van specialismen en expertise en ter verlaging van de drempel voor het instellen van cassatie. De advocaten-generaal bij het ressortsparket verbonden aan de cassatiedesk beslissen of een ingesteld beroep moet worden gehandhaafd en stellen de schriftuur op, waarvan het concept wordt voorgelegd aan de behandelend officier van justitie of advocaat-generaal. De cassatiedesk beslist ook of er aanleiding is voor het doen van verzoeken aan de Procureur-Generaal bij de Hoge Raad tot het vorderen van cassatie in het belang der wet. De cassatiedesk voert een 'offensief' beleid. Zie daarover: Openbaar Ministerie Jaarbericht 2006, p. I4.

I7. Zie Van Dorst, Cassatie, p. 107 e.v.

I8. Zie HR 25 maart 2003, NJ 2003, 329 en HR 26 februari 2002, NJ $2003,557$.

I9. Gedefiniëerd in art. I38 Sv. Daarnaast wordt als einduitspraak beschouwd de niet-ontvankelijkverklaring in het aangewende rechtsmiddel. Ook tegen de beslissing op een vordering tot ontneming van wederrechtelijk verkregen voordeel (art. 5IIe Sv) staat cassatie open.

20. Art. 427 , tweede lid, Sv. Te kort gezegd staat geen cassatie open als geen andere straf of maatregel is opgelegd dan een geldboete tot in totaal $€ 250$ of minder. Zie over de gevallen waarin het eindarrest een misdrijf en een overtreding betreft, of waarin is vrijgesproken van een primair tenlastegelegd misdrijf, maar veroordeeld voor de subsidiaire overtreding: Van Dorst, Cassatie, p. 2I.

2I. Zie over dit concentratiebeginsel: Van Dorst, Cassatie, p. 23-27. Tot de belangrijkste tussenbeslissingen behoren de verstekverlening (art. $280 \mathrm{~Sv}$ ), de verwerping van een preliminair verweer (art. $283 \mathrm{~Sv}$ ), de beslissing op de vordering tot wijziging van de tenlastelegging (art. 313 Sv) en de beslissingen op ter terechtzitting gedane verzoeken (art. $328 \mathrm{~Sv}$ ), in het bijzonder verzoeken tot het horen van getuigen of deskundigen.

22. Zie Van Dorst, Cassatie, p. I87 e.v.; C.J.G. Bleichrodt, Art. 430 Sv en het onrechtmatig verkregen bewijs, DD I982, p. 476 e.v.; D.H. de Jong en J.L. van der Neut, De bescherming in cassatie van de vrijspraak en het ontslag van alle rechtsvervolging, RMThemis, I982, p. 228-260; J. Simmelink en J.L. van der Neut, Consistentie in cassatie? DD I982, p. 568-585; A.A. Franken en C. Waling, De actuele betekenis van artikel $430 \mathrm{~Sv}, \mathrm{NJB}$ 200I, p. I366-I37I. 
rie opgeworpen cassatieklachten tegen vrijspraken die steunen op ontoereikend bewijsmateriaal. ${ }^{23}$

Partieel cassatieberoep is in beginsel mogelijk (art. 429 Sv). Op straffe van nietontvankelijkheid is onder meer een beperking tot alleen tussenbeslissingen of tot alleen de nevenbeslissing over de vordering van de benadeelde partij ${ }^{24}$ evenwel niet toegelaten. De Hoge Raad pleegt een volgens de door de verdachte ingediende akte van cassatie onbeperkt ingesteld beroep in de praktijk soepel te beperken tot de voor de verdachte nadelige beslissingen. De verplichte procesvertegenwoordiging en het openstaan van cassatie tegen vrijspraken maken dit overigens niet meer in alle gevallen vanzelfsprekend. ${ }^{25}$

2.3 Art. 432 Sv regelt de termijn van het instellen van het cassatieberoep. Hoofdregel is dat beroep moet worden ingesteld binnen veertien dagen na de einduitspraak. Deze regel geldt ingeval de dagvaarding in persoon is betekend of de verdachte in rechte (in persoon of bij uitdrukkelijk gemachtigde raadsman ${ }^{26}$ ) is verschenen of wanneer anderszins blijkt van een omstandigheid dat de verdachte met de dag van de terechtzitting tevoren bekend was. In andere gevallen geldt dat de termijn begint te lopen nadat zich een omstandigheid heeft voorgedaan waaruit bekendheid met de uitspraak voortvloeit. Indien alleen het openbaar ministerie bij het desbetreffende gerecht beroep heeft ingesteld, kan de verdachte zijnerzijds alsnog beroep in cassatie instellen (art. 433, tweede lid, Sv). De algemene formaliteiten die bij het instellen van cassatie in acht genomen moeten worden staan vermeld in art. 449-45Ia Sv. Is door of namens de verdachte het verkeerde rechtsmiddel ingesteld dan converteert de Hoge Raad dit in het juiste. ${ }^{27}$

Met ingang van I oktober 2000 is een wezenlijke verandering in de procedure aangebracht. Sindsdien eist art. $437 \mathrm{~Sv}$ op straffe van niet-ontvankelijkheid de indiening door een raadsman van een schriftuur houdende de middelen van cassatie. Als het gaat om de verdachte moet het tijdig ${ }^{28}$ - binnen twee maanden na de aanzegging aan de verdachte van ontvangst van de stukken van het geding bij de Hoge Raad (art. $435 \mathrm{~Sv}$ ) - door zijn raadsman worden ingediend, die daartoe bepaaldelijk gevolmachtigd moet zijn (art. 452, tweede lid, Sv) en de schriftuur moet hebben ondertekend. De schriftuur mag ook per fax worden ingediend; het origineel moet dan worden nagestuurd. De raadsman dient daarbij zelf de verantwoordelijkheid voor de inhoud van de middelen te dragen. Louter als doorgeefluik van door de verdachte

23. Weliswaar geldt vanzelfsprekend ook hier de regel dat de selectie en waardering van het voorhanden materiaal aan de feitenrechter is voorbehouden, maar het aangescherpte motiveringsvoorschrift van art. 359, tweede lid, Sv brengt mee dat in dit verband ook kan worden geklaagd over het ontbreken van een (toereikende) respons op door het openbaar ministerie onderbouwde standpunten, bijvoorbeeld een in het requisitoir gepresenteerde bewijsconstructie. Zie o.m. HR II april 2006, NJ 2006, 393 m.n. YB.

24. Zie HR i9 mei ig87, NJ i988, 3 I6.

25. Zie: Van Dorst, Cassatie, p. 39-40.

26. Zie art. 279 Sv en HR 8 januari 2002, NJ 2002, 339 m.n. Sch. onder NJ 2002, 338.

27. Daarover: Van Dorst, Cassatie, p. 46-48.

28. De rolrechter kan desverzocht wegens bijzondere omstandigheden enig uitstel van de indieningstermijn verlenen. 
opgestelde klachten fungeren mag hij niet. ${ }^{29} \mathrm{Na}$ afloop van de indieningstermijn kunnen geen middelen meer worden voorgesteld. De bij schriftuur voorgestelde middelen plegen in de schriftuur te worden toegelicht, maar zij mogen ook nadien mondeling of schriftelijk worden toegelicht (art. 438, tweede lid, Sv), zij het dat daarbij geen nieuwe middelen kunnen worden voorgesteld of eerder ingediende onvoldragen middelen kunnen worden aangevuld. ${ }^{30}$ Mondelinge toelichting komt vanwege de daaraan verbonden beperkingen sporadisch voor.

Indien het openbaar ministerie in cassatie is gekomen, heeft de raadsman van de verdachte de bevoegdheid dit beroep tegen te spreken (art. 438 , tweede lid onder a, Sv). ${ }^{3 \mathrm{I}}$

Als raadsman kan elke Nederlandse (of in de Europese Unie ingeschreven) advocaat optreden. ${ }^{32}$ Een afzonderlijke Haagse cassatiebalie, zoals in civilibus, bestaat niet. ${ }^{33}$

Op de daarvoor bepaalde rechtsdag neemt het Parket zijn schriftelijke conclusie (art. 439, eerste lid, Sv). Daarvan wordt afgezien als geen middelen van cassatie zijn ingediend (art. 439, tweede lid, Sv). Een afschrift van de conclusie wordt aan de raadsman van de verdachte gezonden (en aan de benadeelde partij namens wie een advocaat middelen heeft ingediend), die daarop binnen twee weken zijn schriftelijk commentaar aan de Hoge Raad kan doen toekomen (art. 439, derde, vierde en vijfde lid, Sv). Deze zogenaamde 'Borgersbrief' is een uitvloeisel van het bekende arrest van het EHRM in de deze zaak. ${ }^{34}$ Van dit commentaar neemt de Hoge Raad kennis en maakt daarvan melding in het arrest. De raadsman heeft slechts eenmaal de bevoegdheid voor een reactie. ${ }^{35}$ Aan de inhoud van niet tijdig ingekomen commentaren gaat de Hoge Raad voorbij.

2.4 Sinds I oktober 2000 wordt de zaak, na het verstrijken van de termijn voor het indienen van middelen, bij de Hoge Raad in behandeling genomen op een openbare

29. Zie: HR I8 juni 2002, LJN AE 2646; HR I9 juni 200I, NJ 2002, 7 m.n. JdH en Richard van Elst, Naar een instrumentele benadering van als middel gepresenteerde klachten en ambtshalve cassatie. In: WB der Nederlanden. 25 jaar wetenschappelijk bureau van de Hoge Raad, p. 209 en daar vermelde rechtspraak.

30. Zie: HR I4 november 2000, NJ 200I, I6 en HR 23 oktober 200I, NJ 2002, 77 m.n. JR.

3I. Vgl. HR 22 mei 200I, NJ 200I, 699.

32. Art. 37 Sv en art. I6b Advocatenwet. Zie over de positie van de raadsman o.m.: G.J.M. Corstens, Het Nederlands strafprocesrecht, vijfde druk, p. 95 e.v.; G. Spong, De raadsman in de cassatiefase, in: Handboek Verdediging, Kluwer Deventer 2003, p. 4I7 e.v.; Taru Spronken, Verdediging, Kluwer Deventer 200I; T. Prakken, Het laatste woord. Zes opstellen over verdediging in strafzaken. Kluwer Deventer 2005; T. Blom en A.R. Hartmann, Verdediging in strafzaken, in: M.S. Groenhuijsen en G. Knigge, Het onderzoek ter zitting, eerste interim-rapport Strafvordering 200I, p. I9523I; A.A. Franken, De Hoge Raad en de cassatieadvocatuur, DD 2005, p. 695-702; A.A. Franken, Traditionele waarden van de advocatuur en schuivende verantwoordelijkheden voor de raadsman, DD 2007, p. 360-369.

33. Over de civiele cassatiebalie: Asser Procesrecht/Veegens-Korthals Altes-Groen (2005), nr. I40. Ook daar speelt de vraag in hoeverre aan de rechtsbijstand in cassatie kwaliteitseisen moeten worden gesteld. Over het nut van een gespecialiseerde strafadvocatuur nog: G. Spong, in: Handboek Verdediging, p. 455.

34. EHRM 30 oktober I99I, NJ I992, 73. Aan het openbaar ministerie dat cassatie heeft ingesteld en de raadsman die dit beroep heeft tegengesproken pleegt ter informatie de conclusie te worden gezonden.

35. HR i6 maart i999, NJ I999, 370. 
zitting van de enkelvoudige kamer (art. $438 \mathrm{~Sv}$ ). Op die rolzitting wordt de datum bepaald waarop het Parket zal concluderen in nieuwe zaken waarin middelen zijn ingediend, worden de conclusies genomen in eerdere zaken (art. 439, eerste lid, Sv), worden de arresten van de Hoge Raad uitgesproken (art. 443 Sv), mededeling gedaan van beslissingen van de rolrechter (bijvoorbeeld op verzoeken tot verlenging van de termijn van indiening van middelen) en is de rolrechter bevoegd de beslissing te geven dat het beroep in cassatie niet-ontvankelijk is, ingeval niet tijdig een schriftuur houdende middelen is ingediend (art. 440, derde lid, Sv). ${ }^{36}$ Ter behandeling van de zaak verwijst de enkelvoudige kamer de zaak naar de meervoudige kamer (art. 438 , tweede lid, Sv).

2.5 Nadat de raadsheer-rapporteur het concept-arrest, voorzien van een toelichting, met het bijbehorende dossier in circulatie heeft gebracht bij de raadsheren die in de zetel zitten, wordt het concept, al dan niet door dezen in de schriftelijke ronde voorzien van opmerkingen, amendementen en alternatieven, aan alle raadsheren gezonden en in raadkamer besproken. Vervolgens wordt, zonodig na nader debat of nadere schriftelijke notawisseling, het definitieve arrest vastgesteld.

2.6 De Hoge Raad heeft, binnen de beperkingen die de cassatiegronden meebrengen, overigens een grote vrijheid bij zijn beslissing. Art. $440 \mathrm{~Sv}$ bepaalt dat de Hoge Raad het beroep in cassatie niet-ontvankelijk kan verklaren, het beroep kan verwerpen of de bestreden uitspraak geheel of gedeeltelijk kan vernietigen, hetzij op de aangevoerde, hetzij op andere - ambtshalve bijgebrachte - gronden. In geval van vernietiging kan de Hoge Raad de zaak zelf afdoen indien dit mogelijk is zonder in een nieuw onderzoek naar de feiten te treden, dan wel de zaak verwijzen of terugwijzen. Voor een bepaald type met nietigheid bedreigd vormverzuim, het ontbreken van de wetsartikelen waarop de straf is gegrond, waarvan vermelding is voorgeschreven door art. 358, vierde lid, Sv, geeft art. 44I Sv de Hoge Raad de bevoegdheid de bestreden uitspraak alleen in zoverre te vernietigen en alsnog de juiste artikelen te vermelden. Ten aanzien van diverse andere met nietigheid bedreigde vormverzuimen is de nietigheid door de Hoge Raad gerelativeerd.

Over de afdoening door de Hoge Raad maak ik nog een enkele opmerking onder 7 .

2.7 Het arrest van de Hoge Raad wordt in het openbaar uitgesproken. Publicatie van de arresten in vaktijdschriften of in digitale informatiesystemen, waaronder de website van de Hoge Raad, vindt op ruime schaal plaats, maar niet zonder meer van elke uitspraak. ${ }^{37}$ Sporadisch wordt de conclusie van de Advocaat-Generaal in een strafzaak gepubliceerd direct nadat deze is genomen, en dus reeds voorafgaande aan de beslissing van de Hoge Raad. Een eenvormig beleid binnen de gehele Hoge Raad

36. Van de in 2006 in totaal 3312 ingekomen rolzaken deed de enkelvoudige kamer 1803 van deze zgn. 'peken' op een eenvoudige en gestandaardiseerde wijze af. Zie: Verslag 2005-2006, p. I76.

37. Zie: Melai/Groenhuijsen, aant. 4 en 5 ad art. 443 Sv. 
bestaat niet. ${ }^{38}$ Door middel van een aankondiging over een te verwachten uitspraak en een samenvatting van de uitspraak zelf wordt in zaken die in de media aandacht hebben getrokken door de Griffier van de Hoge Raad voorlichting aan de pers verstrekt. ${ }^{39}$

\section{De Hoge Raad als cassatierechter}

3.I Art. 79 RO bepaalt dat cassatie mogelijk is wegens (I) schending van het recht, met uitzondering van het recht van vreemde staten en (b) verzuim van vormen voor zover de niet-inachtneming daarvan uitdrukkellijk met nietigheid is bedreigd of zodanige nietigheid voortvloeit uit de aard van de niet in acht genomen vorm. ${ }^{40}$ Art. 43I Sv omschrijft deze vormverzuimen nader; zij betreffen niet alleen verzuimen in het vonnis of arrest zelf, maar geven ook grond voor nietigheid als zij hebben plaatsgehad in de loop van het rechtsgeding. In dit verband wordt hier slechts gewezen op de ontwikkeling van wettelijk voorgeschreven aan vormverzuimen te verbinden nietigheid naar door de rechter na belangenafweging te bepalen rechtsgevolgen: art. $359 \mathrm{~S}$ Sv. ${ }^{4 \mathrm{I}}$ De relativering van de rechtsgevolgen van verzuimen en deze keuzevrijheid voor de rechter vormen enerzijds het sluitstuk van een ook in de jurisprudentie van de Hoge Raad ingeslagen weg, maar markeren anderzijds een beginpunt waar zij de vraag oproepen in welke mate de toepassing daarvan door de feitenrechter, in het bijzonder uit een oogpunt van rechtseenheid, controle behoeft. ${ }^{2}$

De grens tussen vormverzuim en schending van het recht is niet scherp. Het toezicht van de Hoge Raad op de beslissingen van de feitenrechter wordt bepaald door het onderscheid tussen in diens uitspraak voorkomende rechtsoordelen, feitelijke oordelen en gemengde oordelen en de daarmee verbonden toets of het oordeel blijk geeft van een onjuiste rechtsopvatting en of dit begrijpelijk is. In beginsel betreedt de Hoge Raad niet het terrein van de feiten en feitelijke waarderingen, maar in het bijzonder door wettelijk voorgeschreven (vgl. art. $359 \mathrm{~Sv}$ ) of in de jurisprudentie ontwikkelde motiveringsvereisten oefent de Hoge Raad - door de oordelen van de rechter op zijn begrijpelijkheid te toetsen - ook hier controle uit op de feitenrechter. Het blikveld van de Hoge Raad is niet meer beperkt tot de bestreden uitspraak en het proces-verbaal van de terechtzitting, maar hij neemt kennis van de toegezonden stukken van het dossier (en van de in antwoord op een verzoek van het Parket (art. I20, tweede lid, RO) of de Hoge Raad (art. 83 RO) nog toegezonden bescheiden).

38. Zie in dat verband o.m.: H.U. Jesserun d'Oliveira, Publiceer conclusies parket Hoge Raad en wel meteen!, NJB 2006, nr. 29, p. I628-I630; Toegang tot rechterlijke uitspraken. Openbaarheid van rechtspraak. VMC studiecommissie onder voorzitterschap van J.M. de Meij, Mediaforum 2006, nr. 4; N. Huls en D. Vermeer, Vertrouwen in en zelfvertrouwen bij de rechterlijke macht, p. 39.

39. Hoge Raad der Nederlanden, Verslag 2005-2006, p. 48 e.v.

40. Zie: Van Dorst, Cassatie, p. 63 e.v.; D.H. de Jongh en J.L. van der Neut, Rechtsschending versus vormverzuim en de afdoening door de cassatierechter, DD I983, p. 390 e.v. en p. 68I e.v.; Ch.J. Enschedé en Th. W. van Veen, Cassatie in strafzaken functioneel en organisatorisch beschouwd, preadvies voor de vereniging voor de vergelijkende studie van het recht van België en Nederland, Tjeenk Willink Zwolle I974, p. I5 e.v.

4I. Zie over deze bepaling: HR 30 maart 2004, NJ 2004, 376 m.n. YB.

42. Zie: Stamhuis, a.w., p. 474. 
De Hoge Raad is aldus in staat zekere feitelijke constateringen te doen, niet alleen voor zover hij deze nodig heeft in verband met de gang van zaken na het instellen van cassatie, maar ook bijvoorbeeld ten behoeve van de controle op de naleving van betekeningsvoorschriften in feitelijke aanleg. Deze 'doorbreking' van de 'papieren muur' maakt hem niet tot een derde feitelijke instantie, maar het heeft bijgedragen aan een verscherpte controle op het werk van de feitenrechter. ${ }^{43}$ Een verhoogde aandacht voor de motivering past bovendien bij de tendens om, mede uit een oogpunt van legitimatie, een ruimere en begrijpelijkere uitleg en argumentatie van de rechter te verlangen. 44

Van andere factoren die de werklast beïnvloeden noem ik slechts de steeds grotere rol die internationale rechtspraak en regelgeving vervult bij de bepaling van de inhoud van het Nederlandse strafrecht en strafprocesrecht en die tot een dynamische aanpassing van ons recht dwingt. 45 Dan doel ik in het bijzonder op de invloed van het EVRM en op de strafrechtsontwikkeling binnen de Europese Unie. Juist op dit vaak lastige en onzekere terrein is de behoefte aan leiding door de Hoge Raad groot.

3.2 Traditioneel wordt de taak van de Hoge Raad als volgt omschreven: het waarborgen van de rechtseenheid, het bevorderen van de rechtsontwikkeling en het bieden van rechtsbescherming. Zie ook art. 8I RO, dat luidt:

'Indien de Hoge Raad oordeelt dat een aangevoerde klacht niet tot cassatie kan leiden en niet noopt tot beantwoording van rechtsvragen in het belang van de rechtseenheid of de rechtsontwikkeling, kan hij zich bij de vermelding van de gronden van zijn beslissing beperken tot dat oordeel.'

De bestaansreden van de cassatierechtspraak ligt in rechtseenheid, rechtsvorming en rechtsbescherming. De wijze waarop en de mate waarin aan deze functies, letterlijk, recht wordt gedaan, hangt af van daartoe gemaakte keuzes en van daartoe gevoerd beleid. Het is in overwegende mate aan de Hoge Raad zelf die keuzes te maken en zijn beleid uit te stippelen. ${ }^{46}$ Door het uitoefenen van zijn controletaak

43. Daarover: Stamhuis, a.w., p. 428 e.v.

44. De invoering van art. 359 , tweede lid, Sv met ingang van I januari 2005 (bij afwijken van door de verdachte of de officier van justitie 'uitdrukkelijk onderbouwde standpunten' dient de rechter in het bijzonder de redenen op te geven die daartoe hebben geleid) is daarvan een voorbeeld (zie: HR II april 2006, NJ 2006, m.n. YB). Evenzo voorstellen vanuit de rechterlijke macht tot begijpelijker en uitvoeriger motiveren; zgn. Promis-project (waarover: HR I5 mei 2007, NJ 2007, 307, m.n. YB en HR I5 mei 2007, NJ 2007, 308).

45. Zie in het bijzonder: Europeanisering van het Nederlands Recht, Opstellen aangeboden aan Mr. W.E. Haak, Kluwer Deventer 2004, in het bijzonder de bijdragen over strafrecht, p. 294 e.v.; André Klip, Europese integratie en harmonisatie en het strafrecht, Preadvies NJV 2006, Handelingen NJV 2006-I, p. I05 e.v.; S. Prechal en R.H. Ooik, De 'Europeanisering' van het recht: gevolgen voor de Nederlandse rechtspraak en A. van der Schans, De gevolgen voor de Nederlandse strafrechtspraktijk, in: Rechtstreeks (uitgave van de Raad voor de rechtspraak) 2006, nr. I, p. 7 e.v.; resp. 24 e.v.

46. Dat constateerde al J.M. Barendrecht, De Hoge Raad op de hei, kwaliteitsbewaking en de leiding over de rechtspraak door de civiele cassatie: een analyse en denkrichtingen voor de toekomst, W.E.J. Tjeenk Willink Zwolle I998, p. 3-23. Zie ook: J.B.M. Vranken, Toeval of beleid? Over rechtsvorming door de hoogste rechters, NJB 2000, p. I-5. 
draagt de Hoge Raad bij aan de kwaliteit van de rechtspleging. Hoever moet de Hoge Raad daarbij gaan?

3.3 Nogal eens wordt betoogd dat arresten van de Hoge Raad waarin principiële materiële rechtsvragen aan de orde zijn of waarin op voor de praktijk nuttige vragen van uitleg wordt beslist van fundamenteler belang zijn en daarom eerder bij de taak van de Hoge Raad passen dan die waarin klachten over een concrete toepassing van een bestaande norm worden behandeld. In het eerste geval worden vooral de rechtsontwikkeling en rechtsvorming gediend, in het tweede ligt de nadruk op de rechtsbescherming. De indringende vraag is gesteld, ook buiten het strafrecht, 47 of het gewicht van deze laatste functie zo zwaar is dat ter uitoefening daarvan ook in toekomst de toegang tot de Hoge Raad gewaarborgd moet blijven. En daarbij heeft men in het achterhoofd de simpele ervaring dat, hoe ruimhartiger de cassatierechter zijn controlefunctie met betrekking tot het individuele belang van de verdachte uitvoert, hoe minder neiging zal bestaan van beroep in cassatie af te zien.

Ik meen dat een discussie over het soortelijk gewicht van rechtseenheid en rechtsvorming tegenover dat van rechtsbescherming niet erg zinvol is. Ik zou in ieder geval niet goed kunnen beredeneren waarom de taak van de cassatierechter op eerstbedoeld gebied wezenlijker zou zijn dan zijn rechtsbeschermingstaak. Beide functies zijn van even groot belang. Al te kort aangeduid, acht ik het belang van de rechtseenheid en rechtsvorming groot omdat dit uit een meer algemeen oogpunt van behoorlijke rechtspleging en het bieden van rechtszekerheid niet kan worden gemist, en is rechtsbescherming even zwaarwegend uit een oogpunt van maatschappelijke aanvaardbaarheid en individuele rechtvaardigheid.

Ik pleit dus voor het handhaven van de traditionele taken. Dat klinkt wel aardig, maar neemt niet weg dat er een grens is aan wat de Hoge Raad praktisch kan verrichten. Bij de selectie van zaken waaraan de Hoge Raad aandacht zal besteden en vooral bij het bepalen van de mate waarin dat gebeurt, kan aan de aard en het doel van deze functies niet worden voorbijgegaan. De criteria aan de hand waarvan de cassatierechter vaststelt hoe ruimhartig en met welke mate van indringendheid hij zich geroepen voelt de normen te bepalen waaraan moet worden voldaan, behoeven niet dezelfde te zijn als die waaraan de cassatierechter toetst welke aandacht hij schenkt aan de beoordeling van de vraag of die normen in concreto goed zijn toegepast. Het debat moet dan ook mijns inziens gaan over de aan te leggen maatstaf ter bepaling van de intensiteit waarmee de Hoge Raad zich met de zaak moet bezighouden bij de uitoefening van zijn normstellende of van zijn rechtsbeschermende taak.

Als een rechtsvraag is voorgelegd - en of dat zo is, vergt, zoals hiervoor onder 3.I aangestipt, ook nog interpretatie, die dus meer of minder royaal kan zijn - zal te bepalen zijn hoe belangrijk beantwoording daarvan is uit een oogpunt van rechtseenheid en rechtsvorming. Bestaat bijvoorbeeld grote onduidelijkheid in de rechtspraktijk over de uitleg van een wezenlijk nieuw wettelijk voorschrift, is dat van ander gewicht dan als het gaat om de interpretatie van een obscure en inmiddels afge-

47. Zie voor het civiele recht het in noot 3 genoemde eindrapport Fundamentele herbezinning Nederlands burgerlijk procesrecht, p. I5I e.v. 
schafte bepaling, waaromtrent een beslissing het belang van de concrete zaak nauwelijks overstijgt. Dat kan een andere mate van aandacht rechtvaardigen, ook in deze vorm dat buiten het middel om beschouwingen ten beste worden gegeven over de kwestie. Als het middel klaagt over de begrijpelijkheid van de motivering van het oordeel van de feitenrechter, zal te bepalen zijn hoe zwaarwegend beoordeling daarvan is uit een oogpunt van rechtsbescherming. ${ }^{48}$ Juist ook de beslissing of een geconstateerd gebrek van dien aard is te achten dat vernietiging moet volgen, vergt een afzonderlijke weging van de in aanmerking te nemen - en, mede met het oog op de voorspelbaarheid: in uitspraken te expliciteren - belangen. Zijn de gebreken van openbare orde en, zo nee, in hoeverre is het algemeen strafvorderlijk belang dat met naleving van een bepaald voorschrift of zekere regel is gemoeid van dien aard dat schending daarvan tot cassatie moet leiden? In hoeverre bevordert de Hoge Raad daadwerkelijk de kwaliteit van het werk van de feitenrechter door, als het ware om pedagogische redenen, aan een verzuim het gevolg van nietigheid te verbinden? Raakt het geconstateerde gebrek essentiële of rechtens te beschermen belangen van de verdachte en, zo nee, wanneer en waarom is cassatie toch aangewezen? En ook ongeacht de aard van de aangevoerde klacht, zou een factor kunnen zijn of de maatschappelijke beroering die een zaak heeft gewekt rechtvaardigt dat deze in cassatie uitvoerig wordt beoordeeld.

Het antwoord op zulke vragen regardeert de meer of minder extensieve mate waarin de cassatierechter zijn taken uitoefent. Ik meen dat in een verstandig antwoord de ruimte kan worden gevonden voor een verantwoorde beperking van het gebruik van schaarse capaciteit.

In huiselijker woorden gezegd: ik moet niet klagen dat ik eindeloze oninteressante motiveringsklachten over natuurlijk nooit helemaal feilloze uitspraken in feitelijke instantie moet beoordelen, als ik elke motivering op een goudschaaltje wens te wegen. En of dat laatste moet, is afhankelijk van rechtspolitieke keuzen. Dat bij die keuze, binnen de bestaande taken van de cassatierechter, het belang van een beheersbare werklast wordt betrokken acht ik alleszins juist. ${ }^{49}$ De uitkomst van die weging bepaalt de Hoge Raad uiteindelijk zelf.

3.4 Over die door de Hoge Raad zelf te verrichten toets maak ik een enkele losse opmerking.

De zaak is in twee feitelijke instanties behandeld. Daarin horen in beginsel alle stellingen, standpunten of verweren met voldoende precisie naar voren te zijn gebracht. Hoe groot de ruimte is of dient te zijn waarbinnen de feitenrechter verplicht is - ook ambtshalve - onderzoek te verrichten of beslissingen te geven, is hier niet aan de orde, maar die ruimte heeft effect op de toetsing in cassatie. Hoe meer processuele en kwalitatieve waarborgen de procedure in feitelijke aanleg bevat dat de behandeling volledig en zorgvuldig is geweest, hoe afstandelijker de toetsing in cassatie kan zijn. Tot die waarborgen behoort ook de kwaliteit van de rechterlijke

48. Vergelijk: Mevis in noot sub VII onder HR I4 maart 2006, NJ 2007, 345 met betrekking tot de mate van indringendheid waarmee de Hoge Raad de selectie en waardering van het bewijsmateriaal door de feitenrechter zou behoren te toetsen.

49. Vergelijk: Buruma in noot 4 en 5 onder HR I5 mei 2007, NJ 2007, 387. 
organisatie zelf. Naar de mate waarin het vertrouwen gerechtvaardigd is dat het met de opleiding van rechters, hun werkbelasting, de inrichting van de organisatie e.d. wel goed zit, behoeft het toezicht minder intensief te zijn. De vraag is, ik stipte dat hierboven al aan, of arresten steeds de beste vorm zijn waarmee de Hoge Raad die kwaliteit van de organisatie kan bewaken. Het kan zijn dat de enkele wetenschap van de mogelijkheid van cassatie tot een verhoging van de kwaliteit van de rechterlijke werkzaamheid als zodanig leidt, maar of vernietiging van een uitspraak omdat daarin domweg een fout is gemaakt dat ook doet, weet ik zo net nog niet. Nagedacht zou moeten worden of de Hoge Raad - in samenwerking met de Raad voor de Rechtspraak als eerstverantwoordelijke voor de organisatie van de gerechten in feitelijke aanleg - niet ook andere vormen van kwaliteitsbevordering kan hanteren, door het signaleren van veel (door een bepaald gerecht of alle gerechten) gemaakte fouten, voorzien van de wijze waarop deze praktisch kunnen worden voorkomen, doordat raadsheren nog meer dan thans cursussen voor de rechterlijke macht verzorgen of anderszins..$^{\circ}$ Daarvoor moet dan tijd kunnen worden vrijgemaakt.

Het past bij een meer op de verantwoordelijkheid van de verdachte en zijn raadsman (en van het openbaar ministerie) als procespartij gerichte benadering van dezen te verlangen dat zij in cassatie eveneens hun standpunten volledig, duidelijk en - ook in cassatietechnisch opzicht - zo goed mogelijk gemotiveerd naar voren brengen. Dan wordt ook duidelijk dat, waarom en hoe dringend een beroep gedaan wordt op de Hoge Raad en ter uitoefening van welke van zijn taken. En als dat niet heel behoorlijk is gebeurd, moet de vraag worden beantwoord of de Hoge Raad die klacht wel zal ontvangen en of en wanneer de Hoge Raad ambtshalve zal ingrijpen.

De Hoge Raad beslist doorgaans in min of meer toevallig aan hem voorgelegde zaken, met het zich daarin toevallig voordoende feitencomplex en in het kader van een gang van zaken zoals deze zich in het voorbereidend onderzoek of in de procedure nu eenmaal heeft voorgedaan. De methodiek van het beslissen op een voorgelegde casus laat niet altijd gemakkelijk toe dat algemene regels worden gegeven die voor de toekomst in een groot aantal soortgelijke gevallen toepasbaar zijn. Het kan in de voorliggende zaak bijvoorbeeld gaan om een bijzonder, weinig voorkomend of zeer complex geval of om een inmiddels gewijzigde wettelijke regel en zo meer. Bedacht moet ook worden dat het, zeker bij open normen of te verrichten belangenafwegingen, veelal niet zozeer aankomt op het stellen van nieuwe (sub)regels, maar op de toepassing van de bekende maatstaf en de waardering van de in aanmerking komende factoren. Dat relativeert de mogelijkheid (of noodzaak) tot rechtsvorming en de mogelijkheid (of noodzaak) van het scheppen van rechtseenheid, ook omdat het formuleren van algemene regels of uitgangspunten veronderstelt dat het maatschappelijk en rechtskundig debat daarover is uitgekristalliseerd en de Hoge Raad daaromtrent voldoende (om te beginnen: door de procespartijen) is ingelicht. De gevolgen van een op te stellen regel laten zich niet zelden nog niet behoorlijk overzien.

50. Zie, mede in verband met het rapport van de Commissie evaluatie modernisering rechterlijke organisatie (Commissie Deetman), ook de opmerkingen van de President van de Hoge Raad in: Verslag 2005 en 2006 , p. I4-I8. 
Deze relativering van de mogelijkheid en gelegenheid tot rechtsvorming heeft ook geleid tot nadenken over betere, meer rationele, instrumenten om daartoe te geraken. Van verruiming van het instituut van cassatie in het belang der wet, ambtshalve cassatie, prejudiciële vragen aan de Hoge Raad, abstracte toetsing (arrêts de reglement), tot het inschakelen van een amicus curiae. ${ }^{5 \mathrm{I}}$ Dat debat is niet afgerond. Niettemin prikkelt het te bedenken hoe de Hoge Raad zijn rechtsvormende taakstelling zo goed mogelijk zou kunnen vervullen. Het Parket neemt in strafzaken in alle zaken conclusies, in tegenstelling tot het gebruik in de Belastingkamer van de Hoge Raad. In fiscale zaken wordt uitsluitend geconcludeerd in de gevallen waarin dit - in eerste instantie door de Advocaat-Generaal bepaald - vanwege het juridisch belang of anderszins aangewezen wordt geacht. Ik meen dit ook in strafzaken een niet onverantwoorde weg kan zijn. Het kan tot verhoging van de kwaliteit van de beslissing van de Hoge Raad in belangrijke zaken leiden als het Parket de ruimte heeft een diepgaande conclusie te nemen, waarin nog meer dan thans al geschiedt uitvoerig op alle aspecten van een vraag kan worden ingegaan. Maar ook nu kan in daarvoor in aanmerking komende gevallen, al dan niet op verzoek van de Strafkamer, een meer diverse voorlichting worden bereikt, bijvoorbeeld door over hetzelfde vraagstuk, dat in verschillende aanhangige zaken aan de orde is, door verschillende AdvocatenGeneraal te laten concluderen. ${ }^{52}$

Het lijkt goed als de Hoge Raad (en de Procureur-Generaal in verband met zijn bevoegdheid cassatie in het belang der wet in te stellen) tijdig signalen krijgt uit de praktijk dat tegenstrijdige uitleg of toepassing van een wettelijke bepaling voorkomt, dat onzekerheid bestaat omtrent de reikwijdte van een voorschrift of regel of de toelaatbaarheid van een bepaalde werkwijze en dergelijke. De Strafkamer heeft, zij het niet heel frequent, overleg met vertegenwoordigers van de gerechtshoven. Daarin worden organisatorische kwesties aan de orde gesteld, kan van de zijde van de Hoge Raad worden gewezen op belangrijke recente jurisprudentie en bestaat gelegenheid om van de gerechtshoven te vernemen met welke problemen zij in de rechtspraktijk worden geconfronteerd. Nagedacht zou kunnen worden over een meer geformaliseerd contact met de gerechten, waaruit een inventarisatie van opgeworpen problemen uit de praktijk zou kunnen resulteren. Zo'n inventarisatie zou kunnen worden gepubliceerd, waardoor de kwesties onder de aandacht van het juridische publiek worden gebracht. Dan zou breder over oplossingen kunnen worden gedebatteerd en zouden problemen eerder en doeltreffender in cassatie aan de orde kunnen worden gesteld. Het zou ook een gremium kunnen opleveren waaraan de Hoge Raad vragen kan stellen wat de praktische gevolgen zouden zijn van een bepaalde soort voorgenomen beslissing. Een dergelijk contact met vertegenwoordigers van de strafadvocatuur bestaat niet. Ik zie geen grond op voorhand aan te nemen dat zoiets uit praktisch oogpunt niet mogelijk of om principiële reden niet wenselijk zou zijn. De uitkomst van deze contacten kan een betere, ook praktisch gerichte, oordeelsvorming van de Hoge Raad bevorderen.

5I. Zie: Vranken, t.a.p. en vgl. de in noot 3 en 4 genoemde literatuur.

52. Dat is bijvoorbeeld gebeurd in zaken met betrekking tot de betekenis van het nieuwe art. 359, tweede lid, Sv, dat heeft geleid tot het standaardarrest HR II april 2006, NJ 2006, 393 m.n. YB. 
3.5 Ambtshalve toetsing in cassatie in strafzaken, 53 dus cassatie buiten de middelen om, verdient nog afzonderlijk aandacht. Voorwaarde voor toepassing van deze discretionaire bevoegdheid is dat het cassatieberoep van de verdachte ontvankelijk is. Dat relativeert direct iets van de betekenis als wordt bedacht dat ondermaatse middelen tot niet-ontvankelijkheid leiden. Van deze bevoegdheid tot ambtshalve cassatie maakte de Hoge Raad ook in de tijd dat de verdachte zonder middelen in te dienen zijn zaak aan de Hoge Raad kon voorleggen in de praktijk terughoudend gebruik. Maar ook als er middelen waren, is de frequentie van ambtshalve toetsing niet goed te bepalen. Voor een deel werd (en wordt) het zicht hierop vertroebeld door een ruime uitleg van het middel. Voorts was (en is) zichtbaar beleid dat de Hoge Raad bij een cassatieberoep van het openbaar ministerie niet ambtshalve casseerde, tenzij dit in het voordeel van de verdachte was. ${ }^{54}$

Met de introductie van de schriftuurverplichting en de verplichte procesvertegenwoordiging met ingang van I oktober 2000 , waarbij de wetgever de ambtshalve toetsing uiteindelijk $\mathrm{k}^{55}$ heeft gehandhaafd, is de rol daarvan opnieuw te bepalen. ${ }^{56}$ Eén van de voor de werklast bezwarende gevolgen van dit instrument is de aanzuigende werking die dit heeft voor de beroepen, in de hoop of verwachting dat de Hoge Raad zelf een doorslaggevend gebrek zal ontdekken. De Hoge Raad heeft dat aspect in eigen hand en zal dienaangaande zelf zijn beleid hebben te bepalen. Dat beleid zal in hoge mate afhankelijk zijn van de visie die men heeft op het belang van de strafvordering tegenover het concrete belang van de verdachte bij vernietiging, de eigen verantwoordelijkheid van de verdediging en op het gewicht dat men, mede in verband daarmee, aan de rechtsbeschermingsfunctie van de cassatierechter toekent. ${ }^{57}$ Uit de rechtspraak kan wel een beeld worden afgeleid van de gevallen waarin de Hoge Raad wel of niet ambtshalve ingrijpt,,$^{8}$ maar een meer principieel getoonzette uiteenzetting daarvan in een arrest ontbreekt tot nu toe. Ik meen dat daarvoor de tijd rijp is. Het beeld dat uit de rechtspraak oprijst is niet eenduidig, om niet te zeggen in zekere mate willekeurig. Daarbij lijkt het bovendien erop of de Hoge Raad zich eerst dan geroepen voelt zich uitdrukkelijk(er) uit te spreken als in de conclusie het ambtshalve punt is gesignaleerd. ${ }^{59}$ Dat biedt ook het Parket geen houvast.

53. Ambtshalve cassatie bestaat niet in civiele zaken.

54. Zie: Van Dorst, Cassatie, p. 9I-92 en p. II8-II9; H.A. van Borselen en G. Mintjes, Ambtshalve cassatie in strafzaken, in: De derde rechtsingang nader bekeken. Opstellen aangeboden aan C. Bronkhorst, Gouda Quint Arnhem, I989, p. 29-51.

55. In het oorspronkelijke wetsvoorstel was afschaffing nog wel opgenomen (Kamerstukken II I997I998, 26 027, nr. 3, p. I30. Daarop is de Minister teruggekomen (Kamerstukken II I998-I999, 26027 , nr. 5, p. 6).

56. Zie de conclusie van Advocaat-Generaal Vellinga voor HR 24 februari 2004, NJ 2004, 477, m.n. YB onder NJ 2004, 476.

57. Zie daarover bijvoorbeeld: D.R. Doorenbos, Ambtshalve cassatie in strafzaken, NJB I998, p. I393I395.

58. Zie: C.J. van der Wilt en M.K.T. Tjiong, Ambtshalve cassatie in strafzaken na invoering van de schriftuurverplichting, DD 2006 nr. 3, p. 303-319.

59. Zoals in HR I9 april 2005, LJN AS 8464 of HR 20 maart 2007, NJ 2007, 398 m.n. Sch., waarin de Hoge Raad overweegt dat niet is geklaagd over de kwestie waaromtrent de A-G ambtshalve tot cassatie adviseerde. 
3.6 Hoe zou dit beleid eruit moeten zien ${ }^{60}$ Naar mijn idee zou voor ambtshalve cassatie geen plaats behoren te zijn bij die gebreken die voor de steller van het middel als zodanig te onderkennen waren, zoals gebreken in de procesgang, de bewijsmotivering, de kwalificatie, de strafmotivering etc. ${ }^{6 \mathrm{I}}$ In zulke gevallen zou ook de thans wel gehanteerde methode van ambtshalve herstel door middel van verbeterde lezing (bijvoorbeeld van de kwalificatie) of door het ambtshalve schrappen van bij vergissing opgenomen passages (bijvoorbeeld van een onderdeel van de bewijsmiddelen of de bewezenverklaring) achterwege moeten blijven. Afzien van ambtshalve ingrijpen zou zich mijns inziens in beginsel ook moeten uitstrekken tot die gebreken die ernstige twijfel oproepen over de strafbaarheid van feit of dader of waarbij wezenlijke voorschriften van processuele aard niet zijn nageleefd. Daarvoor geldt immers eveneens dat deze zonder meer door een middel aan de orde hadden kunnen worden gesteld en dat te eerder, omdat deze gebreken naar hun aard in het oog hadden kunnen (en dus behoren te) springen. Voor uitzondering zou hoogstens plaats kunnen zijn in die gevallen waarin vaststaat dat strafrechtelijke aansprakelijkheid ontbreekt, zoals in het geval dat geen toepasselijke wettelijke strafbepaling kan worden aangewezen of indien de opgelegde sanctie geen wettelijke grondslag heeft. ${ }^{62}$ Ook verjaring in feitelijke aanleg zou zo'n grond kunnen vormen. ${ }^{63}$ Gelet op de betrekkelijk onvoldragen positie van de benadeelde partij in cassatie, zou ook bij fouten die diens vordering raken ambtshalve optreden geboden kunnen zijn. ${ }^{64}$ En ten slotte zou kunnen worden gedacht aan gevallen waarin ingrijpen geboden is in verband met de consistentie in samenhangende zaken van medeverdachten die bij de Hoge Raad aanhangig zijn. ${ }^{65}$

Een eigen categorie vormen de gevallen waarin de Hoge Raad (veeleer) als feitenrechter optreedt, zoals bij de beoordeling van de ontvankelijkheid van het cassatieberoep, de ontvankelijkheid van het openbaar ministerie in verband met verjaring in de cassatiefase of overlijden van de verdachte en vooral bij de beoordeling van de redelijke termijn in de cassatiefase. Voor deze gevallen geldt dat zulks vrijwel nooit

6o. In de periode mei 2004-mei 2007 gaat het om II6 zaken waarin een ambtshalve vraagstuk aan de orde kon zijn. In 57 zaken zag de Hoge Raad reden om ambtshalve woorden aan dit punt te wijden. De standaardzaken betreffende overschrijding van de redelijke termijn in cassatie en de ongeveer 40 zaken waarin verjaring van overtredingen speelde, zijn niet meegerekend.

6r. Bij wijze van voorbeeld: HR I3 februari 2007, LJN AZ 328I (geen klacht over beslissen in gewijzigde samenstelling van het Hof zonder instemming van de verdachte; art. 322, derde lid, Sv); HR 29 mei 2007 , LJN BA I644 (ontbreken van elke strafmotivering). In deze gevallen strekte de conclusie tot ambtshalve vernietiging op deze punten.

62. Dat bleek in I9 van de onderzochte zaken grond voor ingrijpen. Een voorbeeld: HR I2 oktober 2004, NJ 2007, Io6 m.n. PMe (verboden combinatie van plaatsing in een psychiatrisch ziekenhuis en schadevergoedingsmaatregel) of HR I9 december 2006, NJ 2007, 30 (gevangenisstraf boven het wettelijk maximum).

63. Zie HR 30 mei 2006, NJ 2006, 366 m.n. PMe. Het in de vorige noot bedoelde betrekkelijk hoge aantal zaken van ambtshalve cassatie wegens verjaring van overtredingen hield verband met een niet geheel geslaagde wetswijziging op dit punt. Een reparatiewet (5 juli 2006, Stb. 2006, 310) heeft dit aantal inmiddels sterk teruggedrongen.

64. In HR 4 juli 2007 , LJN AW 2536 had het Hof verzuimd te beslissen op een vordering van de benadeelde partij en vernietigde de Hoge Raad op dit punt ambtshalve.

65. Vergelijk HR I4 september 2004, NJ 2004, 575 met HR I4 september 2004, LJN AP4I34. 
in de schriftuur aan de orde gesteld kan zijn. ${ }^{66}$ Die situaties vallen echter buiten het eigenlijke ambtshalve ingrijpen van de Hoge Raad als cassatierechter, terwijl aan dit ingrijpen veelal mede een doelmatigheidsaspect kleeft.

Ik vrees overigens niet dat de voorgestelde uiterst terughoudende toepassing van ambtshalve cassatie tekort zou doen aan de rechtsvormende taak van de Hoge Raad. Niets staat eraan in de weg dat de Hoge Raad, al dan niet naar aanleiding van beschouwingen daarover in de conclusie, aan het zich in die zaak voordoende probleem ambtshalve aandacht besteedt, zonder dat dit leidt tot vernietiging van de bestreden uitspraak. De omstandigheid dat het voor de verdachte een bittere pil kan zijn te vernemen dat de bestreden uitspraak zou zijn vernietigd als daarover behoorlijk was geklaagd, acht ik niet doorslaggevend. Dat kan zich ook in andere gevallen voordoen, zoals bij een medeverdachte die spijt heeft zelf niet in cassatie te zijn gekomen of bij cassatie in het belang der wet. Soms kan gratie een uitweg zijn.

3.7 Tot op heden is ook de vraag of ambtshalve ten nadele van de verdachte die beroep heeft ingesteld zou mogen worden gecasseerd niet uitdrukkelijk in een arrest aan de orde geweest. Verdedigd zou kunnen worden dat het beroep van de verdachte uit zijn aard geacht moet worden niet gericht te zijn tegen onjuiste, te zijnen voordele strekkende, beslissingen van de rechter, zodat het beroep daartegen 'kennelijk niet is gericht' en de rechtspraak van de Hoge Raad laat van deze oplossing een enkel voorbeeld zien. ${ }^{67} \mathrm{Ik}$ meen dat daaruit hoogstens kan worden afgeleid dat de Hoge Raad niet geneigd is zonder meer ten nadele van de verdachte te casseren, maar niet dat dit is uitgesloten. In ieder geval wordt niet ten voordele van de verdachte ambtshalve ingegrepen als dit ten nadele van de benadeelde partij zou zijn. ${ }^{68}$ Het traditioneel bestaande uitgangspunt is dat bij OM-cassaties ambtshalve niet ten nadele van de verdachte wordt ingegrepen. ${ }^{69}$

Bij een beleid dat erop is gericht van dit instituut uiterst spaarzaam gebruik te maken, is er ook geen reden om nauwgezet te gaan zitten spitten in het dossier of ten nadele van de verdachte nog iets kan worden aangedragen. Maar niets belet de Hoge Raad het geconstateerde gebrek aan de kaak te stellen, zonder te casseren.

3.8 In het voorgaande nam ik de bevoegdheid ambtshalve te casseren tot uitgangspunt. Aan die bevoegdheid is de verplichting verbonden daarvan steeds gebruik te maken als zich de gelijke gevallen voordoen waarin men tot ingrijpen had besloten.

66. En soms ook niet aan de orde gesteld mag worden: een middel dat erop speculeert dat de redelijke termijn zal worden overschreden is niet als middel toegelaten: HR 22 oktober 2002, NJ 2003, I54. De Hoge Raad casseerde bij overschrijding van de redelijke termijn ook ambtshalve bij een OMcassatie (HR I9 december 2006, NJ 2007, 29).

67. Zie: HR II april 2006, NJ 2006, 263 (waarin het Hof ter zake van de opgelegde schadevergoedingsverplichting in strijd met de wet geen vervangende hechtenis had bepaald; de Advocaat-Generaal had op dit punt tot ambtshalve cassatie geadviseerd) en HR I5 maart 2005, LJN AS 4749 (tardief hoger beroep, waarin echter voor de verdachte gunstige beslissingen waren genomen). Voorstander van ambtshalve cassatie ten nadele van de verdachte: A-G Vellinga in Conclusie LJN BB 4853 (nrs. I23 e.v.).

68. Zie: HR 7 september 2004, NJ 2005, 99 m.n. PMe.

69. Daarover ook: D.H. de Jong, De positie van de verdachte in de cassatiefase, DD I988, p. 988-990; J. Simmelink en J.L. van der Neut, Consistentie in cassatie?, DD I982, p. 569-576 en 583-584. 
Daarmee is de invloed op de werkbelasting gegeven. Er bestaan mijns inziens evenwel nog steeds aanvaardbare redenen om deze mogelijkheid na invoering van de schriftuurverplichting met de verplichte procesvertegenwoordiging te schrappen. ${ }^{70}$ Aan de rechtsbescherming van de verdachte wordt in ruime mate voldaan door de hierboven gesignaleerde greep die de Hoge Raad uitoefent op de juistheid en begrijpelijkheid van de beslissingen van de feitenrechter, in het bijzonder door zijn controle op de toereikendheid van de motivering. Ik vermag niet in te zien dat niet van degene die cassatie aantekent mag worden gevergd dat hij klaagt over wat hem bezwaart. Het strookt met de eigen verantwoordelijkheid van de verdediging voor een behoorlijk verloop van het strafproces dat zij de redelijke en evenwichtige processuele verplichting heeft die aspecten aan te dragen die zij aan de rechter wil voorleggen. Zij mag verwachten dat de rechter aan die aspecten behoorlijk en gemotiveerd aandacht schenkt. Maar het volstaat als de rechter zich concentreert op hetgeen aldus is naar voren gebracht. Dat geldt in beginsel in feitelijke aanleg; het geldt evenzo in cassatie. De enkele tegenwerping dat de rechter steeds een eigen verantwoordelijkheid behoudt voor de uitkomst van het strafgeding ${ }^{7 \mathrm{I}}$ moge van gewicht zijn, zij maakt mij niet duidelijk waarom de cassatierechter over zo'n algemeen, inhoudelijk niet nader gespecificeerd, vangnet moet beschikken, ook in gevallen waarin over het gebrek had kunnen worden geklaagd. Toepassing is voorts afhankelijk van de, in wezen toevallige, aanwezigheid van een - behoorlijk middel..$^{72}$ Uit een oogpunt van algemene bescherming van verdachten tegen onrecht wordt dus maar beperkt soelaas geboden. Een uitzondering zou kunnen worden gemaakt voor de hoogst uitzonderlijke gevallen, waarin zich een onvoorziene (en door het middel dus niet te treffen) wijziging van omstandigheden voordoet die het algemeen belang van de strafrechtelijke rechtsorde in de kern raakt of de legitimatie van de strafrechtspleging als zodanig betreft. In andere noodgevallen is er ook altijd nog de weg van herziening of een soortgelijk instrument.

\section{$4 \quad$ De aan het middel te stellen eisen}

4.I Aan de eis dat het middel een stellige en duidelijke klacht over de schending van een bepaalde rechtsregel en/of het verzuim van een toepasselijk voorschrift bevat, zoals het criterium naar vaste rechtspraak luidt, wordt niet zelden 73 niet voldaan. Dat leidt soms zelfs tot niet-ontvankelijkheid van het beroep als geen middel dit minimumniveau haalt.

De toetsing die de Hoge Raad in cassatie dient uit te voeren heeft vanzelfsprekend betekenis voor de (minimum)eisen die aan het cassatiemiddel moeten worden

70. Een pragmatisch argument tegen afschaffing zou juist erin zijn gelegen dat ambtshalve cassatie werkbesparend is omdat de Hoge Raad zich niet in bochten hoeft te wringen om de juiste klacht in het niet rake middel te lezen. Aldus: W.E. Haak, Naar een optimale beoordeling in cassatie van het straf(proces)recht, in: Glijdende schalen, Liber Amicorum J. De Hullu, Wolf Legal Publishers 2003, p. 2I2-2I3.

7I. Zo Stamhuis, a.w., p. 480 .

72. Zie: HR I5 oktober 2002, LJN AE 7382; HR 22 oktober 2002, NJ 2003, I54.

73. Zie: Van Elst, a.w., p. 207-208. 
gesteld: de opsteller van de schriftuur zal onder meer in het oog moeten houden dat de klacht een feitelijke grondslag heeft, dat de klacht gericht moet zijn tegen beslissingen van de rechter en niet enkel tegen de motivering, dat een zuivere rechtsklacht alleen kan slagen als die beslissing onjuist is, ongeacht de motivering, dat bij de klacht een rechtens te respecteren belang moet bestaan (zoals bijvoorbeeld niet het geval is bij overwegingen ten overvloede) en, meer algemeen, dat de Hoge Raad geen derde feitelijke instantie is, zodat niet voor het eerst in cassatie feiten kunnen worden aangevoerd of verweren kunnen worden opgeworpen waarvoor een feitelijk onderzoek nodig is, of klachten kunnen worden geuit die de feitelijke selectie en waardering van bewijsmateriaal betreffen. ${ }^{74}$ In talloze zaken moet worden geconstateerd dat aan deze basisregels is voorbijgegaan. Dit blijken inhoudelijk kansloze beroepen te zijn.

Dat roept ook de vraag op in welke mate het ontbreken van een duidelijk beeld omtrent de proceskansen in cassatie aan deze beroepen debet is en dus welke aspecten cassatie voorspelbaar maken. Daarvan is recent verslag van onderzoek gedaan. ${ }^{75}$ Opvallend daarin is overigens dat de Hoge Raad in de onderzoeksperiode het vaakst casseerde bij wat als de uitoefening van de rechtsbeschermingsfunctie kan worden gezien, te weten in gevallen van overschrijding van de redelijke termijn als bedoeld in art. 6 EVRM (ook ambtshalve - dat is veeleer: als feitenrechter - voor zover het betreft de cassatiefase). ${ }^{76}$ Naar mijn indruk is dat ook na die onderzochte periode nog steeds het geval. Daarvan gaat, op zijn zachtst gezegd, niet de aandrang uit van cassatie af te zien wegens de voorspelbaarheid van een verwerping van het beroep. Deze aardige hoeveelheid zaken met standaardafdoening, veelal leidende tot enige strafvermindering, zouden eigenlijk nauwelijks mogen voorkomen. Afdoening binnen de redelijk geachte termijn is evenwel geen probleem dat met strafprocessuele maatregelen kan worden bestreden, maar bij uitstek een kwestie van interne organisatie van de gerechten, de Hoge Raad incluis. Oplossing van die praktische knelpunten zou voor een inhoudelijk zinvollere tijdbesteding van de Hoge Raad een stuk schelen.

4.2 De voorstellen van de Commissie Haak77 die hebben geleid tot de invoering van het schriftuurvereiste en de verplichte procesvertegenwoordiging van de verdachte door zijn raadsman gingen gepaard met het advies om door de Nederlandse Orde van Advocaten een opleiding tot gespecialiseerde strafcassatieadvocaat te laten inrichten en alleen een gedegen opgeleide specialist toe te laten tot de procesvertegenwoordiging. Dat voorstel heeft de minister niet overgenomen en het is niet te

74. Zie daaromtrent bijvoorbeeld: Van Dorst, Cassatie, p. 85 e.v.; G. Spong, De raadsman in de cassatiefase, in: Handboek Verdediging, Kluwer Deventer 2003, p. 432 e.v.; J. Reijntjes in noot NJ 2002, 77.

75. J.C.M. Couzijn, Kans op cassatie in strafzaken, empirisch onderzoek naar cassatieberoepen in dagvaardingszaken afgehandeld door de Hoge Raad in de periode van I997 tot en met 200I, diss. Leiden 2007.

76. Couzijn, a.w., p. 468 en 482 e.v. Genoemd wordt een gemiddeld percentage van 42,4 van de tot cassatie leidende beroepen in de onderzoeksperiode (p. 500).

77. Commissie Werkbelasting Strafkamer Hoge Raad. De toegang tot de cassatierechter in strafzaken. I996, onder leiding van de oud-president van de Hoge Raad mr. W.E. Haak. 
verwachten dat zodanige verplichte opleiding op korte termijn van de grond zal komen. Maar ook overigens waren deze voorstellen gedaan in de verwachting dat de inschakeling van een advocaat beroepen in kansloze zaken zou beperken en de kwaliteit van de rechtspleging ten goede zou komen doordat meer en beter onderbouwde rechtspunten aan de orde zouden worden gesteld. Het is ook mijn indruk dat die verwachtingen niet ten volle zijn uitgekomen. ${ }^{78}$ Dat laat zich niet alleen verklaren door de toch als moeilijk ervaren cassatietechniek, zeker voor een advocaat die slechts incidenteel in cassatie optreedt, en de betrekkelijk karige rechtsbijstandsvergoeding ${ }^{79}$ die niet stimuleert vele uren te besteden aan een doorwrocht (al dan niet negatief) cassatieadvies. Maar ook, en wellicht waarschijnlijker, hangt dit samen met te respecteren opvattingen binnen de advocatuur over de aard van de belangenbehartiging van de verdachte door een advocaat. Waarom zou deze de beoogde filterfunctie moeten verrichten en op voorhand bijvoorbeeld behoren af te zien van mogelijkheden uitstel van executie te bewerkstelligen of tot korting leidende problemen met de redelijke termijn van behandeling van de strafzaak op te roepen? Het gebruik van de zeeffunctie van de (al of niet gespecialiseerde) advocaat als instrument om de toegang tot de cassatie te bewaken lijkt theoretisch en praktisch beperkt, ${ }^{80}$ terwijl moet worden toegegeven dat ook op het eerste gezicht niet kansrijke beroepen, waarin verdedigbare middelen de Hoge Raad proberen te doen terugkeren van eerdere opvattingen, tot voor de rechtsontwikkeling verrassende resultaten hebben geleid. ${ }^{8 \mathrm{I}}$ Dat neemt niet weg dat een goede gespecialiseerde strafcassatiebalie noodzakelijk blijft, zo niet in het belang van de Hoge Raad, dan toch in dat van de verdachte.

4.3 Ik meen dat het in de voornaamste plaats de verantwoordelijkheid van de Hoge Raad is zijn eigen werklast te bewaken door aan kansloze beroepen zo snel mogelijk een einde te maken. Dat kan in de eerste plaats door strikt de hand te houden aan de beoordeling van de kwaliteit van de middelen, zoals deze op basis van de schriftuur tot ons komen. Dat het blijkens de jurisprudentie met de niet-ontvankelijkheid wegens ondermaatse middelen wel schijnt mee te vallen, wordt nu nogal eens verdoezeld door verwerping van het beroep met behulp van de, hierna onder 5 te bespreken, verkorte motivering als bedoeld in art. 8I RO. Maar ook in die gevallen waarin na enige bestudering van de relevante stukken zonneklaar blijkt van een

78. Aldus ook: Van Dorst, Cassatie, p. 50.

79. In art. I5 Besluit vergoedingen rechtsbijstand 2000 is geregeld dat de vergoeding voor de werkzaamheden van de raadsman op wiens advies het cassatieberoep wordt ingetrokken dezelfde is als voor de raadsman die geen middelen heeft ingediend, nl. 50\% van de vergoeding voor het indienen van middelen.

8o. Hierover onder meer: G. Spong, in: Handboek Verdediging, p. 4I9-420 en 453; Taru Spronken, Verdediging. Een onderzoek naar de normering van het optreden van advocaten in strafzaken, Gouda Quint, Deventer 200I, p. 284 e.v.; G.J.M. Corstens in: Herziening rechterlijke organisatie. Verslag van het symposium van 22 juni 1990 georganiseerd door de Faculteit der Rechtsgeleerdheid Katholieke Universiteit Nijmegen in samenwerking met de Stichting Studiecentrum Rechtspleging, W.E.J. Tjeenk Willink Zwolle I990, p. I72 e.v.

8I. Zie: H.K. Elzinga, een onderzoek naar het aanwenden van rechtsmiddelen in het strafrecht en een vergelijking met het instellen van bezwaar en beroep in de Awb, Gouda Quint, Deventer I998, p. 340 . 
kansloos beroep wegens gemis aan feitelijke grondslag, miskenning van de vaste juridische maatstaf, recente andersluidende jurisprudentie, louter tegen feiten of feitelijke waarderingen opkomende klachten en dergelijke, zijn de middelen ondermaats. Ik acht het op zichzelf zuiver als ook in deze gevallen de niet-ontvankelijkheid zou worden uitgesproken. Van een duidelijke zichtbaarheid in de rechtspraak van de hoeveelheid beroerde middelen zou op deze wijze een nadrukkelijk signaal kunnen uitgaan hoe het staat met de kwaliteit van de schrifturen.

4.4 Wat de kwaliteit van de middelen betreft speelt ook het volgende. De Hoge Raad pleegt geen hoge eisen te stellen aan de inrichting van de middelen en de schriftuur van de raadsman welwillend uit te leggen. Ook klachten die niet in het middel maar, vaak nogal terloops, in de toelichting voorkomen worden veelal als voor bespreking in aanmerking komend beschouwd. Datzelfde geldt voor gevallen waarin niet of nauwelijks wordt gemotiveerd waarom de aangevallen beslissing onjuist of onbegrijpelijk is, als al voldoende scherp is aangegeven tegen welk oordeel de klacht zich richt en welk rechts- of motiveringsgebrek daaraan kleeft. Verwijzingen naar literatuur of rechtspraak komen naar mijn indruk niet zo geregeld voor als men op het niveau van de cassatie zou veronderstellen. Argumenten voor èn tegen een bepaald standpunt, een gemotiveerde conclusie waarom de ene reeks argumenten de doorslag moet geven of waarom het voorliggende geval moet worden onderscheiden van dat uit eerdere jurisprudentie, zal men toch zelden aantreffen. Kennelijk vertrouwen stellers van middelen erop dat het Parket in zijn conclusie de zaken grondig uitzoekt en motiveert en zo de Hoge Raad van goede voorlichting voorziet en gaat men ervan uit dat de Hoge Raad het recht kent (en ambtshalve ingrijpt). Dat alles is juist. Het is echter de vraag of deze welwillendheid, ook na invoering van de verplichte procesvertegenwoordiging, nog steeds op zijn plaats is en nog past bij de verantwoordelijkheid die de verdediging heeft om op juiste en gemotiveerde wijze redelijkerwijze alleen die kwesties aan de Hoge Raad voor te leggen waarop hij, gelet op de cassatiegronden, behoort te beslissen. Dat heeft de Hoge Raad zelf in de hand. Ik zou ervoor pleiten met verantwoorde gestrengheid de kwaliteit van de middelen te bewaken en voor een full-dress behandeling, met conclusie en al, pas te kiezen als daartoe enige indicatie bestaat. Anders bestaat het gevaar dat het schaarse goed van de cassatieprocedure bij welhaast op voorhand kansloze beroepen in feite slechts een interessante standpuntwisseling tussen Parket en, al was het maar in raadkamer, de Raad oplevert.

4.5 De vraag is of van het middel dient te worden verlangd dat het duidelijk maakt welk rechtens te respecteren belang bij de klacht in cassatie bestaat. Dat de betrokkene bij het cassatieberoep belang moet hebben is vanzelfsprekend. Het adagium: point d'intérêt, point d'action geldt ook in strafzaken. ${ }^{82}$ Dit beginsel past de Hoge Raad herhaaldelijk toe. ${ }^{83}$ Bij het ontbreken van belang volgt niet-ontvankelijkheid.

82. Zie in strafvorderlijk verband o.m.: Van Dorst, Cassatie, p. 35 e.v.; G. Spong, in: Handboek Verdediging, p. 432 en 44I-442. Geen belang bestaat bijvoorbeeld bij beroep van de verdachte tegen nietigverklaring van de inleidende dagvaarding (HR 2 november I999, NJ 2000, I44) of tegen vrijspraak van de tenlastegelegde opzetvariant (HR I6 mei 2006, NJ 2007, 3I2, m.n. Kn.). 
Dat van het ontbreken van belang eerst sprake is in geval van misbruik van recht ${ }^{84}$ zou ik een te strenge eis achten. Dat strookt ook niet met rechtspraak van de Hoge Raad. ${ }^{85}$ Niet altijd is precies herkenbaar in welke gevallen en waarom de Hoge Raad wel of niet een voldoende belang aanwezig acht. ${ }^{86}$ De Hoge Raad zou op dit punt mijns inziens een duidelijker en voorspelbaarder beleid moeten voeren.

Vaak zal uit de klacht zonder meer duidelijk zijn welke belang daarbij bestaat. Maar men kan zich gemakkelijk gevallen denken dat dit niet aanstonds in het oog springt. Dan mag mijns inziens redelijkwijze worden gevergd dat uitdrukkelijk wordt toegelicht waarin dit belang gelegen is. ${ }^{87}$ Zoals de Hoge Raad bijvoorbeeld overwoog in verband met het motiveringsvoorschrift van art. 359 , tweede lid, Sv: ${ }^{88}$ 'indien het gaat om een uitdrukkelijk onderbouwd standpunt van het openbaar ministerie, [kan] de verdachte in cassatie in de regel niet met vrucht (...) klagen over de nadere motivering van de afwijking van dat standpunt van het openbaar ministerie dan wel over het ontbreken van die nadere motivering. De verdachte mist immers in het algemeen een rechtens te respecteren belang bij zo een klacht. Hetzelfde geldt voor het openbaar ministerie ten aanzien van uitdrukkelijk onderbouwde standpunten van de verdachte.' Dan valt er dus (op straffe van niet-ontvankelijkheid) in de schriftuur wat uit te leggen.

\section{De motivering van de arresten van de Hoge Raad}

5.I Meer dan de helft van de niet-peken wordt integraal afgedaan met de bovengeciteerde verkorte motivering van art. 8I RO. In die zaken is geconcludeerd door het Parket en heeft de Hoge Raad de zaak bestudeerd. Door deze bepaling wordt dus niet de toegang tot de Hoge Raad beperkt, zoals in enig verlofstelsel. De verkregen besparing in tijdbeslag ligt in het kunnen achterwege laten van het formuleren van een op het middel toegesneden respons. Hoewel blijkens de geschiedenis van de totstandkoming van deze bepaling ${ }^{89}$ ook het Parket op deze verkorte wijze zou kunnen concluderen, wordt dat tot op heden niet gedaan. Dat betekent dat in de conclusie, meer of minder sober, in beginsel alle klachten worden besproken. Wezenlijke besparing levert dit thans voor het Parket dus niet op.

Toepassing van art. 8I RO vindt niet alleen plaats bij integrale verwerping van het beroep, maar ook met betrekking tot afzonderlijke klachten of onderdelen daarvan.

83. Zie bijvoorbeeld: HR 20 april 2004, LJN AN 9378 (geen belang bij toepassing art. 56 Sr i.pv. $57 \mathrm{Sr}$ in verband met hetzelfde strafmaximum en bij klacht over het niet toevoegen van stukken in zaak van de medeverdachte).

84. G.J.M. Corstens, Het Nederlands strafprocesrecht, vijfde druk, p. 7 I9.

85. Bijvoorbeeld: HR I8 februari 1997 , NJ I997, 4II.

86. In HR 3 I mei 2005, LJN AT 3673 werd geklaagd over het niet toepassen van aftrek van inverzekeringstelling en voorlopige hechtenis (art. $27 \mathrm{Sr}$ ), terwijl zo'n vrijheidsbeneming in werkelijkheid niet was toegepast. De Advocaat-Generaal concludeerde tot niet-ontvankelijkheid wegens gebrek aan redelijk belang. De Hoge Raad verwiep het beroep met toepassing van art. 8I RO, kennelijk ervan uitgaande dat het middel feitelijke grondslag miste.

87. Aldus ook: J. Reijntjes in noot bij HR 23 oktober 200I, NJ 2002, 77.

88. HR 3 oktober 2006, NJ 2006, 549.

89. Kamerstukken II I987-I988, I9 953, nr. 5 (Memorie van Antwoord), p. 7. 
Volgens het EHRM is de huidige wijze van afdoening met de aan art. 8I RO ontleende motivering niet onverenigbaar met art. 6 , eerste lid, EVRM. ${ }^{\circ 0}$

Juist de omstandigheid dat in de conclusie de klachten worden besproken en tot verwerping wordt geconcludeerd, al of niet voorzien van het advies tot toepassing van art. 8I RO, brengt mee, zo wordt vaak gesteld, dat de Hoge Raad met een gerust(er) hart kan volstaan met de verkorte motivering. In de conclusie kan de betrokkene immers in ieder geval lezen langs welke weg een antwoord zou kunnen worden worden bereikt. Het bezwaar dat vooral van de zijde van de advocatuur wordt geopperd dat bij de verkorte motivering geen werkelijke uitleg wordt gegeven waarom de klachten falen, wordt aldus enigszins ondervangen. Ik heb overigens niet de indruk gekregen dat de conclusie in de perceptie van de procespartijen die uitlegfunctie ook daadwerkelijk vervult. Als dat juist is, is het de vraag of van het Parket die moeite moet blijven worden verlangd.

In sommige gevallen gaat de Hoge Raad ertoe over aan de bedoelde standaardformule een korte aanduiding te verbinden van een nadere motivering, bijvoorbeeld door verwijzing naar het (standaard)arrest waarin dezelfde of een overeenstemmende klacht in uitgeschreven vorm is behandeld. ${ }^{9 \mathrm{I}}$ Dat is een werkwijze die mijns inziens bepaald perspectief biedt en nog verder zou kunnen worden ontwikkeld, zeker ook als bij evidente beslissingen van een conclusie zou worden afgezien.

Het feit dat de Hoge Raad volstaat met toepassing van art. 8I RO betekent overigens niet dat hij daarom in alle opzichten met de tot verwerping strekkende conclusie instemt, doch alleen dat hij, na beoordeling van het beroep, evenmin grond voor cassatie ziet. Wel is de conclusie gerechtvaardigd dat de Hoge Raad het dan in beginsel globaal met de Advocaat-Generaal eens is.

5.2 Sinds bijna twee jaar volgt de Strafkamer de volgende werkwijze. De beide vicepresidenten, met twee leden van het wetenschappelijk bureau, buigen zich wekelijks over de zaken waarin het Parket heeft geconcludeerd alle middelen af te doen met toepassing van art. 8I RO. Zij bestuderen ieder de helft van deze conclusies met de daaraan gehechte schrifturen. Vervolgens komt dit team (in de wandeling het $8 \mathrm{I}$ RO!-team) bijeen en wordt in overleg besloten welke zaken evident voor de verkorte motivering in aanmerking lijken te komen. In die zaken makkt een lid van het wetenschappelijk bureau, in voorkomende gevallen na een in het overleg opgekomen vraagpunt te hebben beantwoord, een concept-arrest met de voorgestelde 8I-ROafdoening. Dit concept, met een toelichting (die veelal betrekkelijk summier kan blijven omdat de beslispunten en de beantwoording daarvan langs standaardlijnen kort kunnen worden aangegeven), gaat met het dossier in roulatie langs de leden van de aangewezen zetel in drie-formatie, het eerst naar de rapporteur. De opgedane ervaring leert dat rapporteur en zetel meestal betrekkelijk weinig tijd aan bestudering kwijt zijn. Voor de raadsheren die niet in de zetel zitten geldt dat in versterkte mate.

De zaken die zich naar het oordeel van het selectieteam niet manifest voor toepassing van art. 8I RO lenen, bijvoorbeeld omdat voor een verantwoord oordeel alsnog

90. EHRM 4 juli 2000, NJ 200I, 40I, m.n. Kn.

9I. Zie bijwoorbeeld HR i9 juni 2007, $\mathrm{NJ} 2007,363$. 
enig nader onderzoek gewenst lijkt, volgen de gewone weg. Het dossier gaat naar de rapporteur en wordt als normaal toegelicht concept in circulatie gebracht. Dat wil niet zeggen dat de zaak uiteindelijk niet integraal met de verkorte motivering wordt afgedaan. Het komt ook voor dat de rapporteur alsnog een uitgeschreven motivering ter verwerping voorstelt of een andere afdoening bepleit. De cijfers over 2006 wijzen uit dat in meer dan $60 \%$ van de gevallen waarin de conclusie het voorstel tot integrale afdoening met 8I RO bevat, het team dit oordeel volgt.

5.3 Deze werkwijze heeft zeker voor stroomlijning en snellere afdoening door de Hoge Raad gezorgd. Bij de invoering van de rolrechter in de strafrechtelijke cassatieprocedure is bij de parlementaire voorbereiding van de zijde van kamerleden de vraag aan de orde gesteld of afdoening van kennelijke niet-ontvankelijkheden, conversiegevallen of van beroepen waarin door het Parket is geconcludeerd tot toepassing van - thans - art. 8I RO niet door de enkelvoudige kamer konden worden afgedaan. De Minister van Justitie deelde mede daarvoor niet te voelen omdat dergelijke afdoeningen niet te verenigen zouden zijn met het administratieve karakter van de rolzitting van de enkelvoudige kamer. ${ }^{92}$ Dat moge in die context juist zijn, het ware te overwegen afdoening door een enkelvoudige kamer (een gewone zetel en niet de rolrechter) het sluitstuk te laten zijn van deze of een soortgelijke werkwijze. Ik zou nog iets verder willen gaan. De voorselectie die nu in feite plaatsvindt door de Procureur-Generaal en de Advocaten-Generaal en hun medewerkers door de tot toepassing van art. 8I RO strekkende conclusie, zou ook binnen de Hoge Raad kunnen plaatsvinden door een rapporteur en zijn medewerker(s). Het gaat in veel gevallen immers om klachten die om voor de hand liggende redenen kansloos zijn en waarvan de reden van hun ongegrondheid in de uitspraak met een enkel steekwoord of verwijzing naar vaste rechtspraak zou vallen aan te duiden. Het Parket zou in die gevallen natuurlijk op de gewone wijze hebben kunnen concluderen of zelfs een, louter formele, '8I RO-conclusie' hebben kunnen nemen, maar erg zinvol lijkt dat niet, mede gelet op de hiervoor in 5.I verwoorde indruk dat de uitlegfunctie van een conclusie in deze zaken wordt overschat. Het Parket zou dan kunnen afzien van het nemen van een conclusie, zoals eerder beschreven voor de zgn. peken. Acht de rapporteur een verkorte afdoening niet manifest, dan kan alsnog een conclusie worden gevraagd en de eerder beschreven of de gewone werkwijze kunnen worden gevolgd. Dat vermindert de werklast van het Parket. Ik verwacht daarvan geen of maar een geringe taakverzwaring voor de Raad als geheel; bestudering van de zaak door de rapporteur vindt thans ook plaats en aan de hand van een door een medewerker voorbereide notitie moet dat niet meer tijd kosten. Op deze wijze vermindert wel de veronderstelde vergroting van de aanvaardbaarheid van een verkorte afdoening die zou uitgaan van een, wel uitdrukkelijk gemotiveerde, conclusie. Maar van de juistheid van die veronderstelling ben ik, gelet op de geluiden die ik uit de praktijk van de advocatuur opvang, nog niet overtuigd. En het gaat ten slotte nog steeds om duidelijk kansloze beroepen, waarvan de Hoge Raad zelf dit na bestudering van de

92. Kamerstukken II I997-I998, 25 240, nr. 6 (Nota naar aanleiding van het Verslag), p. 3. 
zaak heeft vastgesteld. Ook hier is het uiteindelijk de rechtspolitieke keuze waarop de werkzaamheden van de Hoge Raad zich dienen te concentreren.

5.4 In de literatuur 93 wordt verdedigd dat art. 8I RO, al dan niet geherformuleerd, een grotere rol zou kunnen spelen bij het terugdringen van de werkbelasting van Raad en Parket.

De discussie draait dan om het volgende. Betekent de huidige tekst dat alleen ongegronde klachten, die daarom niet tot cassatie kunnen leiden, op de verkorte wijze kunnen worden afgedaan, maar gegronde klachten, die - ook als de geconstateerde gebreken niet ernstig zijn en met een kleine hersteloperatie kunnen worden opgelost - niet tot cassatie behoeven te leiden, daarvan zijn uitgesloten? De wetsgeschiedenis wekt daaromtrent wellicht enige twijfel. Ik meen evenwel dat de huidige tekst bepaald toelaat dat ook op zichzelf terechte klachten die naar het oordeel van de Hoge Raad uiteindelijk niet tot cassatie leiden door art. 8I RO worden bestreken. Van het type gebreken die niet van zodanig ernstige aard zijn dat cassatie en verwijzing of terugwijzing moet volgen, bestaan - in toenemende mate naar het lijkt - vele voorbeelden. ${ }^{94}$ Indien de Hoge Raad bevindt dat een dergelijke verbetering aangewezen is, zou eveneens met verkorte motivering kunnen worden volstaan, zo nodig voorzien van een korte aanduiding van de reden daarvan, bijvoorbeeld door verwijzing naar het soort geval dat hier speelt uit eerdere jurisprudentie. Iets dergelijks gebeurt in feite nu al in de gevallen waarin de Advocaat-Generaal constateert dat een klacht slaagt, maar betoogt dat dit niet tot cassatie behoeft te leiden, en de Hoge Raad zonder meer volstaat met toepassing van art. 8I RO.95

Tegen toepassing van een verkorte motivering in deze gevallen van, thans nog op zichzelf als terecht aangemerkte, klachten over verzuimen die door de Hoge Raad zonder bezwaar kunnen worden hersteld en daarom in uitgeschreven vorm worden verbeterd, bestaat mijns inziens te minder bezwaar als gelet wordt op het navolgende. Voor herstel is plaats omdat de verdachte daardoor niet in enig rechtens te respecteren belang wordt geschaad. Dat kan ook aldus worden geformuleerd dat de gegrondheid van het middel in het midden wordt gelaten ${ }^{96}$ en direct wordt doorgestoten naar het ontbreken van belang; dan is van vernietiging formeel geen sprake

93. Zie J. de Hullu, Rechtsbescherming door beslissen, rechtsontwikkeling door motiveren, NJB 2002, p. 30I-305; W.E. Haak, Naar een optimale beoordeling in cassatie van het straf(proces)recht, in: Glijdende Schalen, Liber Amicorum J. de Hullu, 2003, p. 203-2I6.

94. De Hoge Raad verbetert de kwalificatie (HR I $_{3}$ februari 2007, NJ 2007, I25), schrapt bijvoorbeeld een kennelijk bij vergissing opgenomen onderdeel in de bewezenverklaring (HR 20 juni 2006, N) 2006, 380; HR I9 september 2006, LJN AX 94Io) of een niet redengevende omstandigheid in de bewijsmiddelen (HR 25 april 2006, LJN AV 6I92; HR 9 januari 2007, LJN AZ 3329), herstelt een verzuim in een bewijsmiddel (ademanalyseformulier) dat zich bij de stukken bevindt (HR II maart 2003, LJN AF 3338) of volstaat met vernietiging van de bewezenverklaring wat betreft het niet uit de bewijsmiddelen af te leiden medeplegen (HR I4 juni 2005, NJ 2006, 65).

95. Bijvoorbeeld: HR 7 maart 2006, LJN AV 0303; HR 20 juni 2006, LJN AV 7258; HR 29 augustus 2006, LJN AX 6417. Ook in gevallen waarin in de conclusie wordt gesignaleerd dat de bewezenverklaring verbetering behoeft omdat daarin bij vergissing een onderdeel(tje) is blijven staan dat niet wordt gedekt door bewijsmiddelen, past de Hoge Raad wel 8I RO toe, dus zonder uitdrukkelijke verbetering; zo bijvoorbeeld: HR I3 februari 2007, LJN AZ 5457; HR 6 maart 2007, LJN AZ 6I22; HR 8 mei 2007, LJN AZ 9352.

96. Vergelijk: HR I2 september 2006, LJN AW 2522, rov. 6.I-6.2. 
meer. Dat geldt ook bij het hanteren van de formulering dat gegrondbevinding zou leiden tot een nieuwe behandeling hetgeen niet in het belang van de verdachte kon zijn. ${ }^{97}$ De grens tussen een gegronde en een ongegronde klacht, en dus tot een op grond van de tekst van art. 8I RO beweerdelijk niet of wel toegelaten verkorte motivering, blijkt dan wel heel dun.

Ik ben dan ook voorstander van toepassing van deze verkorte motivering ook bij op zichzelf gegronde klachten die om voormelde redenen niet tot cassatie kunnen leiden.

En ik zie, ten vervolge op wat ik onder 4.3 opmerkte over de op zichzelf gerechtvaardigde niet-ontvankelijkverklaring van, kort gezegd, kansloze middelen en kansloze beroepen, uit praktische overwegingen niet altijd heel dringende aanleiding om die niet-ontvankelijkheid ook steeds consequent uit te spreken. De ervaring leert dat beantwoording van de vraag of het middel nog net wel of net niet voldoet aan de daaraan te stellen eisen soms meer tijd en debat vergt, dan het moeite kost om te achterhalen dat de klacht zelfs bij de meest welwillende uitleg niet opgaat. En een klacht die, hoe fraai zij ook strookt met de aan een middel te stellen eisen, feitelijke grondslag mist, kan nooit tot cassatie leiden. Daarom volstaat ook in deze gevallen de verkorte motivering van 8I RO. Nadeel is wel dat daarmee de schijn wordt gewekt dat toepassing van art. 8I RO steeds betekent dat het middel of het beroep onder de maat was, zoals van de kant van de advocatuur nog wel eens wordt gedacht. Dat is niet zo, omdat de verkorte motivering juist ook van pas komt in de meerderheid van zaken waarin, ondanks goede en serieuze klachten, desniettemin het bestreden oordeel in stand kan blijven.

5.5 Met betrekking tot de werkwijze bij de verkorte afdoening zou kunnen worden overwogen deze nog verdergaand te vereenvoudigen. Daartoe zou een regeling kunnen worden ontworpen die in zeker opzicht analoog is aan art. 439, tweede lid, Sv en art. 440, derde lid, Sv: het Parket zou geen conclusie behoeven te nemen en de beslissing zou door een Enkelvoudige Kamer (niet zijnde de rolrechter) moeten kunnen worden gegeven. Elke zaak zou eerst door de daartoe aangewezen raadsheer, bijgestaan door een lid van het wetenschappelijk bureau, moeten worden beoordeeld op zijn merites wat betreft de eisen waaraan het middel moet voldoen. Doet zich een geval voor waarin naar het oordeel van de rapporteur art. 8I RO zou moeten worden toegepast dan zou dit met de redenen daarvoor op een eenvoudig werkformulier kunnen worden aangetekend. Deze rapportage zou in het overleg van bijvoorbeeld de beide voorzitters kunnen worden besproken. Wordt geen aanleiding gezien de zaak aan behandeling door de meervoudige kamer te onderwerpen, zal de zaak aldus en enkelvoudig kunnen worden afgedaan. Bestaat voor meervoudige behandeling enige aanleiding, dan zou een conclusie kunnen worden gevraagd en de zaak de gewone weg kunnen volgen. Ook zaken die zich op het eerste gezicht al niet voor toepassing van art. 8r RO lenen, kunnen zo wellicht sneller in het daartoe geëigende circuit worden gebracht.

97. Zie: HR I mei I99o, NJ I99o, 783. 
5.6 De Hoge Raad pleegt in zijn arresten niet - en zeker niet uitdrukkelijk - te antwoorden op, laat staan in discussie te gaan met, literatuur of de conclusie. Uit de gebezigde motivering kan soms worden afgeleid waarom de Hoge Raad afwijkend oordeelt. Een aanzet voor een antwoord op het betoog in de conclusie is soms wel te vinden, vooral in de context van een door de Advocaat-Generaal ambtshalve aan de orde gestelde kwestie of door deze bepleit ambtshalve ingrijpen. ${ }^{9}{ }^{8} \mathrm{Ik}$ zou voorstander zijn van een minder terughoudende opstelling. Mede met het oog op het voortgaande juridische debat kan het bepaald verrijkend zijn de argumenten van de Hoge Raad explicite op tafel te hebben.

Maar ook tegenover de verdediging is de Hoge Raad traditioneel karig in zijn weerlegging van aangedragen argumenten, en al helemaal als het gaat om die welke in de Borgersbrief zijn genoemd in reactie op het betoog van de Advocaat-Generaal. Het past bij het belang van een bredere motivering als de Hoge Raad daarmee in voorkomende gevallen wat minder zuinig zou omgaan.

In het verband van de motivering van zijn arresten is ook verdedigd dat de Hoge Raad blijk zou moeten geven van 'dissenting en concurring opinions' 99 De argumenten van de voorstanders hebben mij bepaald niet overtuigd. Daarvoor hecht ik bijvoorbeeld te sterk aan het in de uitspraak neergelegde resultaat van de, door het geheim van de raadkamer gewaarborgde, vrije en gemeenschappelijke besluitvorming. Ik vrees dat dit proces door het fenomeen van de 'dissenting opinion' op ongelukkige wijze zou kunnen worden doorkruist. Ik ben bang dat ik te snel aan mijn eigen - ik voeg overbodig toe: vermeende - gelijk zou vasthouden, minder gemakkelijk bereid zou zijn mij te laten overtuigen door argumenten van anderen en niet lang genoeg zou zoeken naar een voor ieder aanvaardbare evenwichtige uitkomst, als ik zonder meer ervoor zou kunnen kiezen mijn van de meerderheid afwijkende opvatting te publiceren. Uiteindelijk vergroot deze vorm van motivering naar mijn opvatting de aanvaardbaarheid van de beslissing niet.

5.7 Apart vermeld ik nog het type arresten waarin de Hoge Raad ter inleiding op de behandeling van een klacht aanleiding ziet in voorafgaande beschouwingen ${ }^{\mathrm{IOO}}$ een overzicht te bieden van de stand van zaken op een bepaald terrein, zelfs met voetnoten waarin naar eerdere jurisprudentie wordt verwezen, of, min of meer praktisch gericht, veel voorkomende kwesties bespreekt en regels voor de toepassing van bepaalde voorschriften geeft. Dat is bijvoorbeeld gebeurd met betrekking tot de gevolgen van overschrijding van de de redelijke termijn als bedoeld in art. 6

98. Zie bijvoorbeeld: HR i9 april 2005, NJ 2007, 386 m.n. dJ (Hoge Raad deelt de opvatting van de A-G) en HR i9 april 2005, LJN AS 8464 (anders dan de A-G kon uit de bewijsmiddelen volgen dat het laten toekijken bij ontuchtige handelingen ontucht opleverde).

99. Daarover bijvoorbeeld: W. van Gerven, RW I997, nr. 7, p. 209 e.v en W.M.E. Thomassen, Het geheim van de raadkamer en de dissenting opinion, NJB 2006, nr. I2, p. 686 e.v. Vgl. ook: W.D.H. Asser, Het geheim van de raadkamer en de vrijheid van publicatie, NJB 2006, nr. I2, p. 69I e.v. P.T.C. Hoefer-van Dongen, De zwarte doos van de raadkamer. Verslag van een discussie, NJB 2006, nr. I2, p. 696-697; N. Huls en D. Vermeer, Vertrouwen in en zelfvertrouwen bij de rechterlijke macht, p. 39 e.v.

ıо. Zie daarover ook: K. Rozemond, Voorafgaande beschouwingen in de strafrechtspraak van de Hoge Raad, NJB 2000, nr. I3, p. 706-7I2. 
EVRM,${ }^{\text {IOI }}$ toepassing van art. $359 \mathrm{a} \mathrm{Sv},{ }^{102}$ betekeningsperikelen, ${ }^{103}$ motiveringsvereisten in verband met art. 359 , tweede lid, $\mathrm{Sv}^{\mathrm{I0}}{ }^{\mathrm{e}}$ en toepassing van het (met ingang van I maart 2007 gewijzigde) art. 4IO Sv en andere bepalingen ter zake van het horen van getuigen in hoger beroep en de indiening van een appelschriftuur. ${ }^{105}$ Tegen deze vorm van weergave en systematisering van eerdere, onoverzichtelijk geworden, jurisprudentie of van het verschaffen van handzame regels voor in de praktijk gerezen onduidelijkheden is wel bezwaar gemaakt, ${ }^{\text {I0 } 6}$ onder meer omdat zulke beschouwingen zouden verplichten daarbij afwijkingen van eerdere uitspraken te vermelden of nadien nuanceringen van eerder gegeven regels aan te brengen of omdat het gevaar bestaat dat in abstracto gegeven beschouwingen te weinig oog hebben voor de concrete omstandigheden van het geval, dan wel te snel verworden tot enkele vuistregels voor de praktijk zonder wezenlijk bij te dragen tot de rechtsvorming. Ik deel die bezwaren niet. Ik meen dat dit type uitspraken een zinvolle bijdrage levert aan de rechtsvorming en de rechtseenheid bevordert. Het biedt ook de mogelijkheid in latere uitspraken (of bij toepassing van art. 8I RO) door een eenvoudige verwijzing naar de desbetreffende rechtsoverweging van het standaardarrest de relevante regel of toepasselijke maatstaf aan te duiden en zo eenvoudiger (nader) te kunnen motiveren. Ook de in de loop der tijd mogelijk noodzakelijke nuanceringen of afwijkingen komen zo, ook voor de Hoge Raad zelf, duidelijker in beeld. En ten slotte zijn zulke arresten van belang in verband met de voorspelbaarheid van de uitkomst van een in te stellen cassatie en kunnen zij bijdragen aan het voorkomen van kansloze beroepen.

De Hoge Raad zou zich feitelijk meer ruimte moeten kunnen verschaffen vaker van dergelijke, bewerkelijke, arresten te wijzen. De hier voorgestelde maatregelen, waaronder een ruimere toepassing van art. 8I RO, zouden kunnen bijdragen aan het verkrijgen van die ruimte.

\section{Cassatie in het belang der wet}

6.I Cassatie in het belang der wet (art. $456 \mathrm{~Sv}$ ) is een buitengewoon rechtsmiddel dat slechts kan worden aangewend als tegen een beslissing enig gewoon rechtsmiddel niet open staat of weliswaar heeft opengestaan maar ongebruikt is gebleven. ${ }^{\text {I07 }} \mathrm{De}$ Hoge Raad is gebonden aan de grondslag van de vordering van de Procureur-Generaal en hij kan niet op andere dan de aangevoerde gronden vernietigen. Cassatie brengt geen nadeel toe aan de rechten door partijen verkregen (art. 78, zesde lid, RO).

IOI. HR 3 oktober 2000, NJ 2000, 72I m.n. JdH en HR 9 januari 200I, NJ 200I, 307 m.n. JdH.

I02. HR 30 maart 2004, NJ 2004, 376 m.n. YB.

I03. HR I2 maart 2002, 317 m.n. Sch.

I04. HR II april 2006, NJ 2006, 393 m.n. YB.

I05. HR i9 juni 2007, LJN AZ I702.

Io6. Vooral door Schalken in zijn noot bij NJ 2002, 317.

I07. Daarover: Van Dorst, Cassatie, p. I03-I04; W.H.B. den Hartog Jager, Cassatie in het belang der wet: een buitengewoon rechtsmiddel, Gouda Quint, Arnhem I994; J. Remmelink, Cassatie in het belang der wet, in: De derde rechtsingang nader bekeken. Opstellen aangeboden aan C. Bronkhorst, Gouda Quint Arnhem I989, p. 253-264. 
6.2 Van de discretionaire en autonome bevoegdheid van de Procureur-Generaal op grond van art. 78 , eerste lid, $\mathrm{RO}$ tot het doen van vorderingen tot cassatie in het belang der wet wordt betrekkelijk spaarzaam gebruik gemaakt. ${ }^{\text {I08 }}$ In de laatste jaren is enige stijging van het aantal waar te nemen. Dat houdt, zoals de Procureur-Generaal heeft uiteengezet, ${ }^{\text {IO9 }}$ verband met de totstandkoming van wettelijke regelingen die beroep in cassatie voor partijen uitsluiten en waarin deze mogelijkheid is opgenomen als middel om rechtseenheid te garanderen en, meer algemeen, met de toenemende aandacht voor de rechtseenheid en het belang dat zo snel mogelijk duidelijkheid ontstaat over vragen van uitleg die (nieuwe) wetgeving oproept. Hij wijst daarbij terecht erop dat de terughoudendheid die in civiele zaken gewenst kan zijn vanwege het feit dat de gewone contradictoire procedure het voordeel heeft dat beide partijen hun standpunten naar voren kunnen brengen, in strafzaken minder speelt.

In de praktijk wordt de beslissing om al dan niet een vordering tot cassatie in het belang der wet in te stellen in vrijwel alle gevallen genomen op grond van een verzoek aan de Procureur-Generaal, afkomstig van het openbaar ministerie, andere gerechten, (semi-)overheidsinstellingen, bedrijven, advocaten of burgers. ${ }^{\text {IIO }}$

6.3 Dit instrument kan uitstekende diensten verrichten om rechtskwesties snel en doeltreffend aan de Hoge Raad voor te leggen. ${ }^{\text {II }}$ Als middel om het hierboven in 3.4 aangestipte belang van minder 'toevallige' cassaties te dienen en zo in het algemeen belang rechtsvorming en rechtseenheid minder afhankelijk te maken van de bereidwilligheid van procespartijen om ten dienste daarvan beroep aan te tekenen en wellicht ook als complement van een zeer terughoudende toepassing van ambtshalve cassatie, verdient het aanbeveling van dit instituut meer gebruik te maken. Daarmee zou ook tegemoet gekomen kunnen worden aan bezwaren die wel zijn opgeworpen tegen het creëren van de mogelijkheid voor de lagere gerechten om zelf prejudiciële vragen aan de Hoge Raad te stellen, zoals vertraging van de behandeling tegen de zin van partijen. Het voordeel van een beslissing op zo'n verzoek van een gerecht aan de Procureur-Generaal de desbetreffende vraag in cassatie aan de orde te stellen, ligt juist in de tussenkomst van deze. Hij kan allicht beter beoordelen of de kwestie zich reeds voor behandeling door de Hoge Raad leent en kan in zijn vordering breder op de problematiek ingaan en argumenten verschaffen die voor en tegen een bepaalde oplossing pleiten.

Mede daartoe zou, door besparing op andere werkzaamheden, aan het Parket de feitelijke ruimte geboden moeten worden vaker cassatie in het belang der wet te kunnen instellen.

I08. In de periode 2005-2006 in 7 gevallen. Zie: Verslag 2005-2006, p. I54.

rog. Verslag 2005-2006, p. I55 e.v.

IIo. Aldus de Procureur-Generaal in: Verslag 2005-2006, p. I54.

III. Voorbeelden: HR I3 juni 2006, LJN AX I662 (wijziging van art. I4a Sr verandering van wetgeving?); HR I5 mei 2007, NJ 2007, 387 m.n. YB (zgn. Promis-project); HR 28 november 2006, LJN AY 663I en AY 6633 (uitleg Overleveringswet). 


\section{$7 \quad$ De afdoening en het geding na cassatie}

7.I Van de mogelijkheid tot partiële vernietiging wordt door de Hoge Raad veel gebruik gemaakt. Gedeeltelijke vernietiging pleegt in voorkomende gevallen met het oog op een doelmatige en efficiënte afdoening na cassatie uitgangspunt te zijn. ${ }^{\text {II2 }}$ In geval van vernietiging kan de Hoge Raad de zaak naar een ander gerecht verwijzen of naar hetzelfde gerecht terugwijzen; is de uitspraak gedaan door een rechtbank, dan naar het gerechtshof van het ressort; is de vernietigde uitspraak gedaan door een gerechtshof, naar een ander gerechtshof (art. 440, tweede lid, Sv). Tegenwoordig pleegt terugwijzen uitgangspunt te zijn. Daarbij wordt ervan uitgegaan dat het verstandig zal zijn dat de zaak in feitelijke instantie niet door een kamer in dezelfde samenstelling wordt behandeld in verband met de mogelijke schijn van vooringenomenheid. Meer dan uitgangspunt is die regel niet. Om allerlei redenen, die ook te maken zouden kunnen hebben met de kans dat bij terugwijzing het gevoel zal bestaan van bevooroordeeldheid van het gerecht, bijvoorbeeld omdat de zaak in het desbetreffende ressort nogal wat ophef heeft teweeggebracht, kan de Hoge Raad de zaak verwijzen naar een ander gerecht.

7.2 Ook het door de Hoge Raad om doelmatigheidsreden zelf afdoen zolang geen onderzoek naar de feiten nodig is, komt in toenemende mate voor. ${ }^{\mathrm{II} 3}$ Dat geldt niet alleen voor gevallen van schending van de wet, waartoe vroeger art. $440 \mathrm{~Sv}$ de afdoening beperkte, maar ook voor vormverzuimen. Regelmatig spreekt de Hoge Raad zelf van een feit vrij, ${ }^{\mathrm{II} 4}$ ontslaat van alle rechtsvervolging ${ }^{\mathrm{II} 5}$ of verklaart de inleidende dagvaarding nietig. ${ }^{\text {II6 }}$ Maar ook kan het voorkomen dat (met partiële vernietiging in zoverre) de straf wordt verminderd, en niet alleen in die talloze gevallen dat dit wegens overschrijding van de redelijke termijn ${ }^{117}$ moet gebeuren.

7.3 De rechter die de zaak na cassatie op het bestaande hoger beroep opnieuw moet berechten is gebonden aan het dictum van het arrest en de omvang van het geschil dat daardoor wordt omlijnd. Consequentie is dat de zaak in zoverre vanaf het instellen van het hoger beroep opnieuw ter berechting voorligt, met inbegrip van hetgeen in eerste aanleg is geschied. Dat wordt nog wel eens miskend. ${ }^{\text {II8 }}$ Ook bij vernietiging door de Hoge Raad wat betreft de strafoplegging kunnen misverstanden rijzen

II2. Zie: Van Dorst, Cassatie, p. 94-95. J. Hielkema, Doel(matig) getroffen maar ook vernietigd? Lotgevallen van strafzaken met terecht voorgestelde cassatiemiddelen, in: Pet af, Liber Amicorum D.H. de Jong, Nijmegen, Wolf Legal Publishers, 2007, p. I37-I53. Een (niet onomstreden) voorbeeld biedt HR I4 maart 2006, NJ 2007, 345 m.n. PMe. Zie ook: Stamhuis, a.w., p. 430-43I.

II3. Vergelijk daarover: conclusie van Advocaat-Generaal Jörg bij HR 25 januari 2005, NJ 2006, 4II. Een aardig voorbeeld geeft HR 8 juli 2003, NJ 2003, 574 en HR Io april 2007, NJ 2007, 223 (shockschade) waarin om doelmatigheidsredenen de vordering van de benadeelde partij niet-ontvankelijk werd verklaard.

II4. Bijvoorbeeld: HR 23 januari 2007, NJ 2007, 337, m.n. F.C.M.A. Michiels.

II5. Bijvoorbeeld: HR 9 februari i988, NJ I988, 6r3 n.n. G.E.M.

II6. Bijvoorbeeld: HR 20 februari $2007, \mathrm{LJN} \mathrm{AZ} 4757$.

II7. Bijvoorbeeld: HR 22 oktober 2002, NJ 2003, I55; HR 26 september 2006, NJ 2006, 539; HR 9 januari $2007, \mathrm{NJ} 2007,50$.

II8. Zie: HR 3I januari 2006, NJ 2007, 286 m.n. De Jongh. Met een in eerste aanleg gewijzigde tenlastelegging moet dus rekening gehouden worden: HR 5 december 2006, NJ 2006, 666. 
als bij meer feiten bijvoorbeeld uitsluitend ten aanzien van één bepaald feit en de (gehele) strafoplegging wordt vernietigd; dan moet de verwijzingsrechter opnieuw een straf opleggen voor alle feiten. ${ }^{\text {II }}$ Complicaties kunnen zich voordoen in verband met een beperking van het cassatieberoep: als bij meerdaadse samenloop het beroep beperkt was tot bijvoorbeeld één van deze feiten en de Hoge Raad daarop dus niet beslist heeft en wat de strafoplegging betreft de bestreden uitspraak heeft vernietigd, zal de verwijzingsrechter voor dat feit een straf moeten bepalen naar analogie van art. 423 , vierde lid, Sv. ${ }^{\text {I2O }}$

Naar mijn ervaring vinden rechters en procespartijen het niet in alle zaken eenvoudig te onderkennen wat de stand van zaken is na cassatie. Het verdient aanbeveling dat de Hoge Raad, meer dan voorheen, ${ }^{\mathrm{I} 2 \mathrm{I}}$ ook in minder gecompliceerde zaken, een duidelijke verwijzingsinstructie opneemt waarmee hij de opdracht voor de feitenrechter nog eens handzaam samenvat. Daarmee kan een op dit punt ongevalsvrije afdoening na cassatie gediend zijn.

\section{Tot slot}

8.I In het voorgaande passeerden, zonder aanspraak op originaliteit of volledigheid, enige binnen het bestaande systeem betrekkelijk eenvoudig in te passen mogelijkheden om de Strafkamer (en het Parket) ruimer dan voorheen gelegenheid te verschaffen zich op meer fundamentele uitspraken te richten. Daarvan zijn een strenge handhaving van aan cassatiemiddelen te stellen eisen, uitgebreidere toepassing van de verkorte motivering als bedoeld in art. 8I $\mathrm{RO}$ - ook in gevallen waarin vernietiging aan de orde zou kunnen zijn maar van cassatie kan worden afgezien wegens gebrek aan concreet belang of doordat het gebrek eenvoudig hersteld zou kunnen worden en afdoening van zaken waarin die verkorte motivering is aangewezen door een Enkelvoudige Kamer, alsmede geen of uiterst terughoudende toepassing van ambtshalve cassatie de belangrijkste. Ook signaleerde ik enkele situaties waarin nadere argumentatie of instructie dan thans gebruikelijk aanbevelenswaardig zou zijn.

Dat alles geschiedde tegen de achtergrond van de aanname dat de grens van hetgeen de Hoge Raad aan werk zou kunnen verzetten dreigt te worden bereikt.

8.2 Rode draad vormde de eigen verantwoordelijkheid en eigen keuze van de Strafkamer zelf. Dat betreft niet louter een efficiëntere strafprocessuele afdoening. Daarachter schuilt vanzelfsprekend de materieelrechtelijke en rechtspolitieke keuze - met de al of niet uitgesproken visie op de taakstelling van de cassatierechter die daarmee verbonden is - naar de mate waarin belang wordt gehecht aan het door middel van vernietiging optreden tegen verzuimen of gebreken in de beslissingen

II9. Zie: HR I7 oktober 2006, NJ 2006, 579.

I20. Zie: HR 27 januari 2004, NJ 2005, 54. Zie in dit verband ook: Van Dorst, Cassatie, p. 99, die nog wijst op de mogelijkheid die de verdachte heeft om zijn beroep te beperken (art. 429 Sv) in verband met de afschaffing van het verbod van cassatie tegen vrijspraken.

I2I. Dat gebeurde bijvoorbeeld in: HR I5 december 1998, NJ I999, 553 en HR I2 november 2002, NJ 2003, 594 . 
van lagere rechters. Als de Hoge Raad bijvoorbeeld strenge eisen stelt aan hetgeen eerst in de aanvulling op het verkorte arrest van het gerechtshof mag worden opgenomen, ${ }^{122}$ verbiedt dat aanvankelijk een zogenaamd uittreksel van de uitspraak is opgemaakt, ${ }^{123}$ gevolgen voor de opgelegde straf verbindt aan het enkele overschrijden van de inzendtermijn ${ }^{124}$ of niet vereist dat in geval van het ontbreken in het dossier van de pleitnota in het cassatiemiddel wordt aangevoerd dat het belang bij de klacht erin is gelegen dat in de pleitnota een stelling was opgeworpen waarop niet of ontoereikend is ingegaan, ${ }^{\mathrm{I} 25}$ heeft dat rechtstreeks gevolgen voor de toestroom van zaken. Een daarop gerichte gegronde klacht heeft immers zonder meer succes. Voor zo'n keuze, in het bijzonder voor een niet te relativeren nietigheid, kunnen uitstekende redenen bestaan. Het is naar mijn opvatting evenwel niet zo dat bij het bepalen van de noodzaak tot vernietiging niet ook als factor zou mogen worden betrokken dat daarvan een zwaardere werkbelasting voor de Hoge Raad of de lagere rechter het gevolg kan zijn. Als een redelijke verdeling van de capaciteit in het gedrang komt, zou op den duur aan heroverweging of nuancering van dergelijke materiële beslissingen wel eens niet vallen te ontkomen.

In het voorgaande ligt besloten dat ik dat debat nu al zou willen aangaan.

8.3 'Zou de wet dan ter wille van den Hoogen Raad gewijzigd moeten worden? Mij dunkt, dat de rechter er is om de wet toe te passen, niet de wet om de taak van den rechter te veraangenamen', schreef Feith. ${ }^{\mathrm{I} 26}$ Ook zonder (ingrijpende) wetswijziging kan, zo hoop ik te hebben duidelijk gemaakt, mijn aangename cassatietaak uitvoerbaar blijven.

I22. Zie: HR 9 november I999, NJ 2000, 7I; HR 23 november I999, NJ 2000, 587; HR I3 juni 2000, NJ 2000, 523; HR 23 januari 200I, NJ 200I, I82 en HR I8 december 200I, NJ 2002, 350.

I23. Zie: HR 24 mei 2005, NJ 2006, 433 m.n. PMe.

I24. Zie: HR 3 oktober 2000, NJ 2000, 72I, rov. 3.3. en 3.5., m.n. JdH.

I25. Zie: HR I december 1999, NJ I999, 470.

I26. HNJV igio, p. 32. 